Article

\title{
Stream Health Evaluation Using a Combined Approach of Multi-Metric Chemical Pollution and Biological Integrity Models
}

\author{
Usman Atique $\mathbb{D}^{D}$ and Kwang-Guk An * \\ Department of Bioscience and Biotechnology, Chungnam National University, Daejeon 34134, Korea; \\ physioatique@gmail.com \\ * Correspondence: kgan@cnu.ac.kr; Tel.: +82-10-6404-9844; Fax: +82-42-882-9690
}

Received: 13 April 2018; Accepted: 15 May 2018; Published: 18 May 2018

\begin{abstract}
Bouchung Stream is a large tributary of the Geum River watershed that is simultaneously affected by wastewater treatment plant effluents and agricultural activities in the watershed area. The focal subject was to diagnose the chemical and biological health of the temperate stream by using a combined approach of the multi-metric water pollution index (WPI) and the index of biological integrity $\left(\mathrm{IBI}_{\mathrm{KR}}\right)$, using datasets from 2008-2014. Water chemistry analyses indicated seasonal and inter-annual variations mainly linked to the intensity of monsoon rainfall in the watershed, potentially causing the availability of agricultural runoff water. The main events of phosphorus inflow and nitrogen dilutions occurred during July-August. Temporal and spatial heterogeneities were observed and were largely recognizable due to nutrient enrichment and organic matter intensification. Chlorophyll showed weak linear relation to total phosphorus $\left(R^{2}=0.17\right)$ but no relation to total nitrogen $(p>0.05)$. Fish compositions analyzed as trophic/tolerance guilds in relation to water chemistry showed visible decline and modifications. Average WPI site scores ranged from 33-23, indicating an excellent upstream to fair downstream water quality status. Correspondingly, $\mathrm{IBI}_{\mathrm{KR}}$ scores ranged between 38-28 approximating with WPI site classification, as well as both indices showed higher regression relation $\left(R^{2}=0.90\right)$. Fish guild analyses revealed tolerant and omnivore species dominating the downstream, while sensitive and insectivores depleting in approximation with changing water chemistry and was confirmed by the principal component analysis. In addition, the fish guilds meticulously responded to phosphorus inflows. In conclusion, overall stream health and water chemistry analyses indicated continuous chemical and biological degradation influencing the trophic and tolerance fish guilds. Moreover, the combined application approach of WPI and IBI $\mathrm{KR}_{\mathrm{R}}$ could help in better understanding the chemical and biological mechanisms in rivers and streams.
\end{abstract}

Keywords: stream health evaluation; chemical pollution; index of biotic integrity; water pollution index; tolerant species; water chemistry

\section{Introduction}

Stream health evaluation has been one of the hottest research areas over the recent decades in developed countries such as U.S.A. [1], Canada [2], France [3], Germany [4], and England [5]. Human interaction with the environment was inevitable and resulted in processes leading to several ecological perturbations in lotic ecosystems. Under such circumstances, simple chemical parametric studies, biological diversity investigations, and composition analyses were frequently carried out by considering those key factors for ecological health evaluations. However, ecological health evaluation in streams and rivers is not so simple, rather it depends on a variety of combined factors. Such factors include water chemistry [6], physical habitat condition in terms of structural components [7], climatic 
and hydrological condition (e.g., precipitation) [8], and biotic compositions [9]—all involved in a variety of ecological functions. Hence, stream health diagnosis has always been vital for stream management and possible restorations. Stream health can degrade by reciprocal damages caused by physical and chemical water quality changes $[10,11]$ that disrupt the stream biota structure, as well as functions [12]. Thus, stream health has become very critical in areas where streams pass through agricultural pastures and urban areas [13].

Stream health assessment could help diagnose the long-term effect of existing chemical stressors that also involve biological indicators in time and space [6]. Recent booms in human population, urbanization, industrialization, and intensive agricultural activities have created uncomplimentary chemical and biological changes in stream ecosystems. Such changes could either lead to altered species composition [14], disturbed trophic state interaction in species [15], or overall decline in species abundance. Recent studies revealed water quality monitoring was not merely enough for diagnosing stream health status, but that biological integrity and ecological interactions were equally important to ascertain stream health [7,16-18].

By keeping the above concepts in view, two of the most important aspects of stream health diagnosis (i.e., water chemistry and biological components) were studied. One of the indices used in the assessment of nutrient pollution was the concept of nutrient pollution index (NPI). It was primarily suggested by Bach [19], and modified by Trivedi et al. [20] to use as a measure for water quality assessment. Dodds et al. [21] in U.S.A. and Lee and An [22] in South Korea successfully applied it to assess nutrient and organic pollution. It can categorize water bodies as oligotrophic, mesotrophic, or eutrophic depending upon the level of organic and nutrient pollutants in ambient water $[7,23]$. Since the metrics used in NPI cannot be categorized as pollutants, nor all as nutrients, a modification of the name for the model from NPI to WPI (water pollution index) was inevitable.

The second was the concept of "integrity", first put forth by Leopold [24] in 1949, referring to such an ecosystem having not altered because of anthropogenic activities. It described the character and condition of an ecosystem that was a product of evolutionary and biogeographic processes [25-27]. The index of biotic integrity (IBI) implemented that all the ecological systems (natural or perturbed) are comprised of biological assemblages that are undergoing continuous interspecific and intraspecific ecological processes in a sustainable manner. Thus, diagnosis of stream health status in comparison to pristine ecosystems may lead to the identification of disturbances in integrity, as well as ecological processes [28-30]. The IBI originally aimed at measuring "multiple biological dimension of complex ecosystems" $[27,29]$. Identification of measureable biological factors that continuously changed along the gradient of study region was the foremost step in IBI research [31,32]. This gradient usually considered multiple environmental stressors that could have distinct effect on aquatic biota. Each biological trait termed as a candidate metric which had a clear relationship to the environmental stressors [7,33-35]. Consequently, the sites with the least or no perturbations were considered healthy and well integrated. The total scores of all metrics defined the integrity of each study site [14,29] and was used to devise measures reflecting how each study site deviated from its natural state of biotic integrity [36], and what possible restoration and conservation measures it could ensue.

The reasons for selecting these two indices as a combined approach included fish as being considered a good biological indicator of environmental stressors in aquatic ecosystems [7,14,29]. The sites which are in headwater stream regions are considered as the reference sites, hence they can be used in comparison with downstream sites to conclude the assessment process [37,38]. It is note-worthy that fish assemblages may vary along the stream gradient based on several biological aspects not limited to species diversity, tolerance to chemical stressors, habitat preference, feeding niches as well as origin of each species [35,39]. Variations among these aspects depict the severity and level of degradation in stream health. One of the best traits of IBI as a tool is that it can be modified to study the regional fish assemblages and their distribution for assessment in countries other than the U.S.A. An et al. [40] modified the IBI model into 08-metrics and then re-modified it into 10 and 11 metrics, primarily considering the local fish fauna and its distribution in South Korea [41]. 
The principal goals were to establish the ecological health status of Bouchung Stream, South Korea, by using a dataset from 2008-2014 on the basis of seasonal, inter-annual variations of physicochemical water quality factors, modified multi-metric water pollution index (WPI), and modified multi-metric index of biotic integrity $\left(\mathrm{IBI}_{\mathrm{KR}}\right)$. Wastewater treatment plant (WWTP) effluents in combination with agricultural runoff mainly affected this stream, leading to water quality deterioration and biological degradation. A simultaneous analysis expected to yield assessments of seasonal and spatial patterns of environmental degradation, as well as changes in fish assemblages viewed though tolerance and trophic guilds.

\section{Materials and Methods}

\subsection{Site Description and Study Duration}

This study was performed in a temperate stream (Bouchung Stream), near Daejeon, South Korea (Figure 1). Bouchung Stream is one of the major streams in the Geum River watershed (3rd largest river watershed in country) stretching to a total length of $72.11 \mathrm{~km}$, with a water basin area $553.38 \mathrm{~km}^{2}$ and a mean slope of $32.1 \%$ rendering a steep gradient for water flow from headwater towards downstream. The four sampling sites (S) are described as follows. S1: 2nd order stream, N: $36^{\circ} 32^{\prime} 22.88^{\prime \prime}$ E: $127^{\circ} 40^{\prime} 50.4^{\prime \prime}$; S2: 3rd order stream, N: $36^{\circ} 29^{\prime} 01.55^{\prime \prime}$ E: $127^{\circ} 43^{\prime} 27.59^{\prime \prime}$; S3: 4th order stream, N: $36^{\circ} 22^{\prime} 26.02^{\prime \prime}$ E: $127^{\circ} 49^{\prime} 12.20^{\prime \prime}$; and S4: 4th order stream, N: $36^{\circ} 17^{\prime} 26.27^{\prime \prime}$ E: $127^{\circ} 41^{\prime} 33.47^{\prime \prime}$.

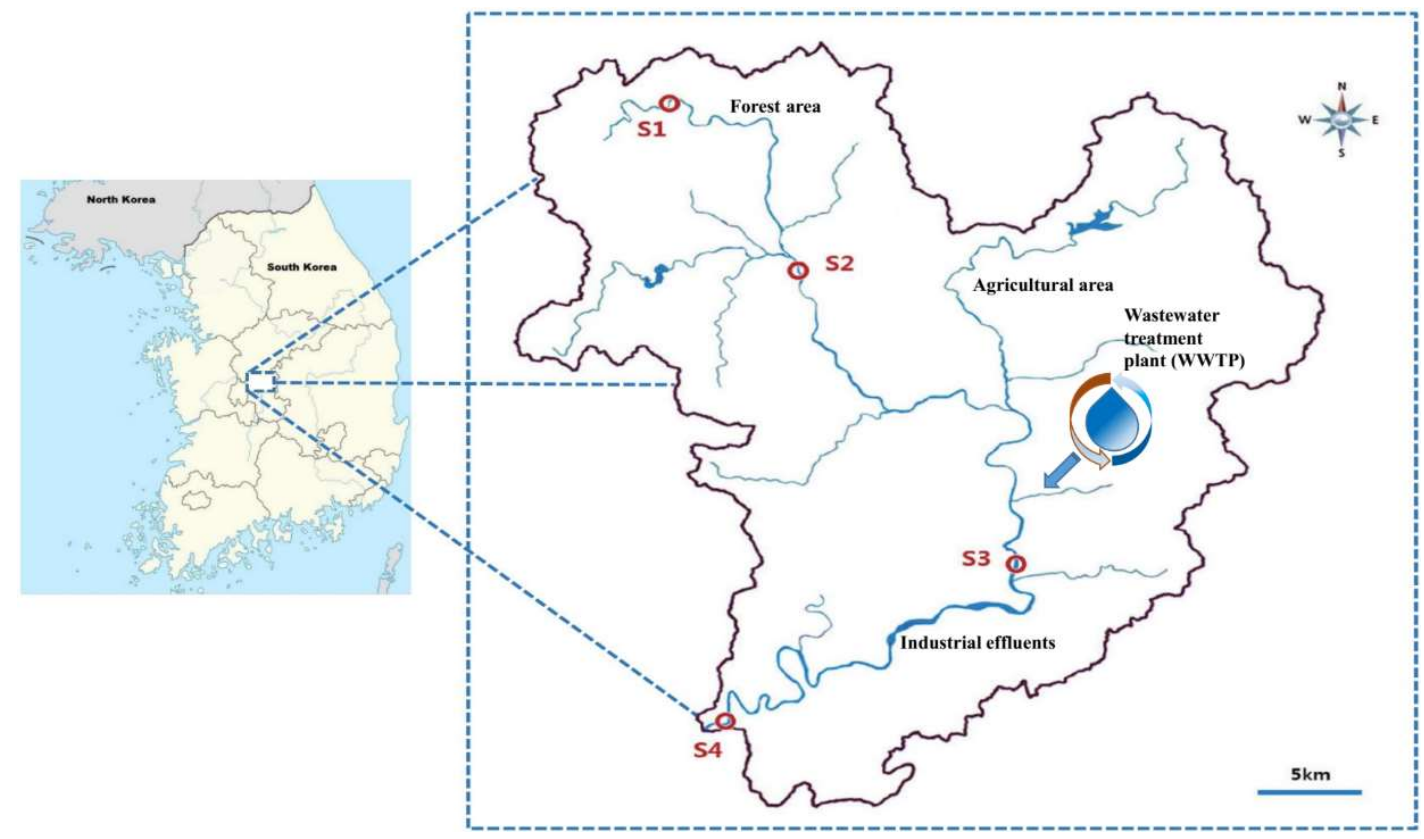

Figure 1. Site map showing the catchment area and sampling sites in Bouchung Stream, South Korea. Area settlements are shown along with the wastewater treatment plant (WWTP).

Forest cover constitutes $67 \%$ of the upstream area and the rest is cropland (26\%) or urban areas $(04 \%)$. Water quality monitoring data was collected on a monthly basis, whereas fish sampling was executed twice a year (i.e., first sampling in the pre-monsoon period from April to June and the second in the post-monsoon period from September to October, 2008-2014). S1 is a headwater stream site and did not receive any non-point source (NPS) pollutants. Sites 2 and 4 did not receive any treated effluents from any WWTP, but agricultural runoff was believed to enter the mainstream originating from the surrounding cropland areas. S3 is near urban areas where it received effluents from WWTPs, as well as industrial effluents. The decision to designating a year as wet or dry was based on the 
intensity of the annual rainfall in the watershed. If the annual rainfall exceeded $1200 \mathrm{~mm}$, the year was designated as a wet year, otherwise as a dry year.

\subsection{Water Chemistry Analyses}

In total, we measured 16 water chemistry parameters during this study. The parameters included $\mathrm{pH}$, dissolved oxygen (DO), water temperature (Temp.), electrical conductivity (EC), total suspended solids (TSS), total number of coliform bacteria, biological oxygen demand (BOD), chemical oxygen demand (COD), total nitrogen $(\mathrm{TN})$, total dissolved nitrogen $(\mathrm{TDN})$, ammonia nitrogen $\left(\mathrm{NH}_{4}-\mathrm{N}\right)$, nitrate nitrogen $\left(\mathrm{NO}_{3}-\mathrm{N}\right)$, total phosphorus (TP), total dissolved phosphorus (TDP), ortho-phosphorus ( $\left.\mathrm{PO}_{4}-\mathrm{P}\right)$, and chlorophyll-a (CHL-a). The $\mathrm{pH}, \mathrm{DO}$, Temp, EC, and CHL-a was measured with a multi-parameter water quality sensor (YSI Sonde 6600, Environmental monitoring system, Yellow Springs, OH, USA). Total number of coliform bacteria (TNCB) was estimated using the standard method [42]. Total nitrogen and TDN were analyzed by method of second derivative after digestion in persulfate solution $[43,44]$. The $\mathrm{NH}_{4}-\mathrm{N}_{\text {and }} \mathrm{NH}_{3}-\mathrm{N}_{\text {were }}$ estimated by phenate method and ion chromatography, respectively, followed by extract filtration of the source water sample through GF/C filters. The TP and allied species (i.e., TDP and $\mathrm{PO}_{4}-\mathrm{P}$ ) were estimated using ascorbic acid method followed by persulfate oxidation [44,45]. TSS, BOD, and COD were measured by following standard methods $[42,44]$. Nutrient analyses were repeated thrice to ensure validity, while the estimation of BOD, COD, and TSS were performed twice [42,46]. The data was collected on a monthly basis throughout the study duration under all hydrological conditions prevailing the stream watershed.

\subsection{Fish Sampling}

Fish sampling was performed as per modified wading method $[47,48]$ for evaluation of stream health which was derived from the Ohio EPA method [49]. Fifty min of fish sampling was based on the catch per unit effort (CPUE) method [49], exploiting all habitat grounds like riffle, run, and pools, with direction from both upstream to downstream, and covering a stretch of at least $200 \mathrm{~m}$. The casting nets had mesh sizes of $5 \times 5 \mathrm{~mm}$ and dimensions of $1.5 \mathrm{~m} \times 1.5 \mathrm{~m} \times 3.14 \mathrm{~m}$, and kick nets had a mesh size of $4 \times 4 \mathrm{~mm}$ and dimensions $1.8 \mathrm{~m} \times 0.9 \mathrm{~m}$, which were used as sampling gear. In situ identification of each fish followed by immediate release to its habitat was performed. All fish specimens were identified observing the salient body features as described by Kim and Park [50], while Nelson's [51] system was followed for systematic classifications. However, if any ambiguity was faced in proper identification, samples were preserved in $10 \%$ formalin solution for further research and identification in laboratory. Based on the concept of Sanders et al. [52], all sampled fishes were carefully examined if they bore any external anomalies such as deformities (D), erosion(s) (E), lesions (L), and/or tumors (T) (DELT) as insight into the status of individual fish health. The trophic and tolerance guild analyses were executed following previously conducted regional studies in South Korea [53].

\subsection{Modified Multi-Metric Water Pollution Index (WPI)}

To perform the chemical health assessment, a modified multi-metric index (WPI) was developed and modified from the NPI. Composed of seven metrics in total, the NPI metrics are detailed in Table 1. The scoring criteria for each metric established for boundaries defined by the third of the observed distributions of obtained values. Therefore, the assigned scoring criteria for each metric was 5, 3, and 1, respectively. The final chemical health assessment of the stream at each site was evaluated after obtaining the total score. It led to a final categorization from excellent (31-35), good (25-29), fair (19-23), poor (13-17), and very poor (07-11).

\subsection{Modified Multi-Metric Index of Biotic Integrity (IBI)}

Development of IBI for regional applications based on identification of ecological perturbations across the study area were followed by biological data collection. Next, was the identification of reckonable characteristics (metrics) of fish assemblages that were considered to be changing or shifting systematically in space and time. Composed of eight metrics, constituting three main categories viz. 
species richness and composition, trophic and tolerance guild compositions, and the fish abundance, along with an insight to physical health condition of fish. The details of metrics mentioned in Table 2 . Half of the eight metrics (i.e., $\mathrm{M}_{1}, \mathrm{M}_{2}, \mathrm{M}_{3}$ and $\mathrm{M}_{7}$ ) were evaluated by maximum species richness line (MSRL) [54], keeping in view the stream order at each site. The scoring criteria for each metric was 5,3 , and 1 followed by the criteria of Reference [1], which reflected that the biotic integrity either approximated, deviated, or greatly deviated from the pristine conditions. The final scores obtained after summing up all metric values led to evaluate as five categories of biological health from excellent (36-40), good (28-34), fair (20-26), poor (14-8) and very poor (08-13). Detailed account of specified metrics and their characteristics as well as the respective scoring standards could be consulted from An et al. [40].

\subsection{Statistical Analysis}

Seasonal and inter-annual deviations of the water quality factors as well as regression analyses were performed on the log-transformed datasets in Sigma Plot version 10 [55]. Means and standard deviations were calculated by using SPPS v.22. PAST software [56] used for principal component analysis (PCA) to assess which factors have changed during the research time in the streams under study, as well as for correlation analysis.

\section{Results and Discussion}

\subsection{Seasonal Variations in Water Chemistry}

Seasonal precipitation pattern was one of the key factors influencing the stream water quality (Figure 2). Seasonally, one third of total precipitation in Korea occurred during the fleeting time of summer monsoon (July-August) and showed conspicuous hydrological variations. The summary statistics of water chemistry factors at the four sites are mentioned in Table 3. The seasonal water quality changes showed identical patterns during the dry season, but summer monsoon rainfall was the critical factor during the study. $\mathrm{pH}$ in downstream ranged higher as compared to the rest of three sites and showed a minimal seasonal change brought about by precipitation. Krishnaram et al. [57] quantified $\mathrm{pH}$ of 6.7-8.4 as safe for aquatic biota for sustainable productivity, while $\mathrm{pH}$ below 4.0 and above 9.6 could be hazardous to fish. All sites showed a reasonable drop in the average values of EC during summer monsoon. Due to agricultural and rainwater inflow, S3 and S4 showed higher levels of TSS and increased with the increasing precipitation and vice versa. Water temperature and salinity level significantly changed the dissolution of oxygen in water [58]. The amount of TSS indicated aquatic pollution caused by extraneous origins and affected running water quality in an adverse manner. Higher contents of TSS increased the density of water, influencing osmoregulation, decreasing gas solubility, as well as other uses of water [59]. Total number of coliform bacteria (TNCB) showed a huge variation in upstream and lesser change in downstream sites and remained unresponsive to the seasonal downpour. Total number of coliform bacteria indicated if the effluents contained fecal matter [60]. The higher the number of bacteria, the higher are the chances of fecal contamination, hence a greater risk water borne diseases would prevail [61,62]. Biological oxygen demand change at S1 was nominal while at S2, S3, and S4, it showed the highest average values from April to June, and then decreasing trend was observed during the summer monsoon and onwards. An almost similar pattern was exhibited by COD, but was less affected by the seasonal rainfall. The higher the values of BOD and COD, the higher were the chances of organic and inorganic pollutants in the water bodies. 
Table 1. Chemical health assessment of Bouchung Stream based on a multi-metric water pollution index (WPI) during 2008-2014.

\begin{tabular}{|c|c|c|c|c|c|c|c|c|}
\hline \multirow{2}{*}{ Category } & \multirow{2}{*}{ Model Metrics (M) } & \multicolumn{3}{|c|}{ Scoring Criteria } & \multicolumn{4}{|c|}{ Mean \pm Standard Deviation (Score) } \\
\hline & & 5 & 3 & 1 & S1 & S2 & S3 & S4 \\
\hline \multirow{3}{*}{ Nutrient Regime } & $\mathrm{M}_{1}:$ Total Nitrogen $(\mathrm{mg} / \mathrm{L})$ & $<1.5$ & $1.5-3.0$ & $>3$ & $\begin{array}{c}1.98 \pm 0.069 \\
\text { (3) }\end{array}$ & $\begin{array}{c}1.98 \pm 0.63 \\
\text { (3) }\end{array}$ & $\begin{array}{c}2.26 \pm 0.614 \\
\text { (3) }\end{array}$ & $\begin{array}{c}1.56 \pm 0.60 \\
\text { (3) }\end{array}$ \\
\hline & $\mathrm{M}_{2}:$ Total Phosphorus $(\mu \mathrm{g} / \mathrm{L})$ & $<30$ & 30-100 & $>100$ & $23.57 \pm 23.02$ & $32.23 \pm 23.72$ & $\begin{array}{l}43.83 \pm 44.02 \\
(3)\end{array}$ & $\begin{array}{l}39.96 \pm 79.64 \\
(3)\end{array}$ \\
\hline & $\mathrm{M}_{3}: \mathrm{TN}: \mathrm{TP}$ ratio & $>50$ & $20-50$ & $<20$ & $\begin{array}{c}163.36 \pm 179.34 \\
(5)\end{array}$ & $\begin{array}{c}100.71 \pm 98.99 \\
(5)\end{array}$ & $\begin{array}{c}86.53 \pm 68.08 \\
(5)\end{array}$ & $\begin{array}{c}101.08 \pm 101.44 \\
\quad(5)\end{array}$ \\
\hline Organic Matter & $\mathrm{M}_{4}:$ Biological Oxygen Demand (mg/L) & $<1$ & $1-2.5$ & $>2.5$ & $\begin{array}{c}0.563 \pm 0.241 \\
(5)\end{array}$ & $\begin{array}{c}0.99 \pm 0.66 \\
(5)\end{array}$ & $\begin{array}{c}1.15 \pm 0.48 \\
\text { (3) }\end{array}$ & $\begin{array}{c}0.85 \pm 0.53 \\
(5)\end{array}$ \\
\hline \multirow{2}{*}{ Ionic Contents and Solids } & $\mathrm{M}_{5}$ : Total Suspended Solid (mg/L) & $<4$ & 4-10 & $>10$ & $\begin{array}{c}1.67 \pm 1.66 \\
\text { (5) }\end{array}$ & $\begin{array}{c}3.44 \pm 4.45 \\
\text { (5) }\end{array}$ & $\begin{array}{c}8.40 \pm 11.50 \\
\text { (3) }\end{array}$ & $\begin{array}{c}12.86 \pm 52.50 \\
\text { (1) }\end{array}$ \\
\hline & $\mathrm{M}_{6}:$ Electrical Conductivity $(\mu \mathrm{S} / \mathrm{cm})$ & $<180$ & $180-300$ & $>300$ & $\begin{array}{c}163.85 \pm 43.03 \\
(5)\end{array}$ & $\begin{array}{c}198.46 \pm 52.67 \\
\text { (3) }\end{array}$ & $\begin{array}{c}231.19 \pm 46.19 \\
\text { (3) }\end{array}$ & $\begin{array}{c}204.92 \pm 44.44 \\
\text { (3) }\end{array}$ \\
\hline Primary Production Indicator & $\mathrm{M}_{7}$ : Sestonic Chlorophyll $(\mu \mathrm{g} / \mathrm{L})$ & $<3$ & 3-10 & $>10$ & $\begin{array}{c}0.671 \pm 1.08 \\
(5)\end{array}$ & $\begin{array}{c}1.31 \pm 1.24 \\
\text { (5) }\end{array}$ & $\begin{array}{c}6.81 \pm 5.58 \\
\text { (3) }\end{array}$ & $\begin{array}{c}5.37 \pm 6.72 \\
\text { (3) }\end{array}$ \\
\hline \multicolumn{5}{|c|}{ Final WPI Scores } & 33 & 29 & 23 & 23 \\
\hline \multicolumn{3}{|c|}{ Water Quality Criteria } & & & Excellent & Good & Fair & Fair \\
\hline
\end{tabular}

Table 2. Biological health assessment of Bouchung stream based on index of biotic integrity $\left(\mathrm{IBI}_{\mathrm{KR}}\right)$ using fish assemblages during $2008-2014$.

\begin{tabular}{|c|c|c|c|c|c|c|c|c|}
\hline \multirow[t]{2}{*}{ Category } & \multirow{2}{*}{$\begin{array}{l}\text { Model Metrics } \\
\text { (M) }\end{array}$} & \multicolumn{3}{|c|}{$\begin{array}{l}\text { Scoring Criteria } \\
(5-1)\end{array}$} & \multicolumn{4}{|c|}{$\begin{array}{c}\text { Sampling Sites } \\
\text { (Obtained Model Values) }\end{array}$} \\
\hline & & 5 & 3 & 1 & S1 & S2 & S3 & S4 \\
\hline \multirow{4}{*}{$\begin{array}{l}\text { Species Richness and } \\
\text { Composition }\end{array}$} & $\mathrm{M}_{1}$ : Total Number of Native Fish Species & \multicolumn{3}{|c|}{ Expectations of $M_{1}$ vary with stream size and region. } & $\begin{array}{l}29 \\
(5)\end{array}$ & $\begin{array}{l}39 \\
(5)\end{array}$ & $\begin{array}{l}46 \\
(5)\end{array}$ & $\begin{array}{l}46 \\
(5)\end{array}$ \\
\hline & $\mathrm{M}_{2}$ : Number of Riffle Benthic Species & \multicolumn{3}{|c|}{ Expectations of $M_{2}$ vary with stream size and region. } & $\begin{array}{l}06 \\
(5)\end{array}$ & $\begin{array}{l}08 \\
(5)\end{array}$ & $\begin{array}{l}10 \\
(5)\end{array}$ & $\begin{array}{l}09 \\
(5)\end{array}$ \\
\hline & $\mathrm{M}_{3}$ : Number of Sensitive Species & \multicolumn{3}{|c|}{ Expectations of $M_{3}$ vary with stream size and region. } & $\begin{array}{l}08 \\
(3)\end{array}$ & $\begin{array}{l}07 \\
(3)\end{array}$ & $\begin{array}{l}13 \\
(5)\end{array}$ & $\begin{array}{l}13 \\
(5)\end{array}$ \\
\hline & $\mathrm{M}_{4}$ : Proportion of Individuals as Tolerant Species & $<5$ & $5-20$ & $>20$ & $\begin{array}{l}05 \\
(5)\end{array}$ & $\begin{array}{l}58 \\
(1)\end{array}$ & $\begin{array}{l}22 \\
(1)\end{array}$ & $\begin{array}{l}45 \\
(1)\end{array}$ \\
\hline
\end{tabular}


Table 2. Cont.

\begin{tabular}{|c|c|c|c|c|c|c|c|c|}
\hline \multirow[t]{2}{*}{ Category } & \multirow{2}{*}{$\begin{array}{l}\text { Model Metrics } \\
\text { (M) }\end{array}$} & \multicolumn{3}{|c|}{$\begin{array}{l}\text { Scoring Criteria } \\
(5-1)\end{array}$} & \multicolumn{4}{|c|}{$\begin{array}{c}\text { Sampling Sites } \\
\text { (Obtained Model Values) }\end{array}$} \\
\hline & & 5 & 3 & 1 & S1 & S2 & S3 & S4 \\
\hline \multirow[b]{2}{*}{ Trophic Composition } & $\mathrm{M}_{5}$ : Proportion of Individual as Omnivore Species & $<20$ & $20-45$ & $>45$ & $\begin{array}{l}05 \\
(5)\end{array}$ & $\begin{array}{l}58 \\
(1)\end{array}$ & $\begin{array}{l}46 \\
(1)\end{array}$ & $\begin{array}{l}58 \\
(1)\end{array}$ \\
\hline & $\begin{array}{c}\mathrm{M}_{6}: \text { Proportion of Individuals as Native } \\
\text { Insectivore Species }\end{array}$ & $>45$ & $45-20$ & $<20$ & $\begin{array}{l}(J) \\
85 \\
(5)\end{array}$ & $\begin{array}{l}(1) \\
32 \\
(3)\end{array}$ & $\begin{array}{l}(1) \\
51 \\
(5)\end{array}$ & $\begin{array}{l}37 \\
(3)\end{array}$ \\
\hline \multirow{2}{*}{$\begin{array}{l}\text { Fish Abundance and } \\
\text { Condition }\end{array}$} & $\mathrm{M}_{7}$ : Total Number of Native Individuals & \multicolumn{3}{|c|}{ Expectations of $M_{7}$ vary with stream size and region. } & $\begin{array}{c}1725 \\
(5)\end{array}$ & $\begin{array}{c}748 \\
(5)\end{array}$ & $\begin{array}{c}1316 \\
(5)\end{array}$ & $\begin{array}{c}597 \\
(5)\end{array}$ \\
\hline & $\mathrm{M}_{8}$ : Percent Individuals with Anomalies & 0 & $0-1$ & $>1$ & $\begin{array}{l}0.0 \\
(5)\end{array}$ & $\begin{array}{c}0.43 \\
(3)\end{array}$ & $\begin{array}{l}0.04 \\
(3)\end{array}$ & $\begin{array}{c}0.06 \\
(3)\end{array}$ \\
\hline \multirow[t]{2}{*}{ Final IBI Scores } & & & & & 38 & 26 & 30 & 28 \\
\hline & ogical Health Status of Stream & & & & Excellent & Fair & Good & Good \\
\hline
\end{tabular}


Table 3. Summary statistics of the water quality parameters in Bouchung stream during 2008-2014.

\begin{tabular}{|c|c|c|c|c|c|c|c|c|c|c|c|c|c|c|c|c|c|}
\hline Sites & Attrib. & $\mathrm{pH}$ & DO & BOD & COD & TN & TP & TN:TP & Temp. & EC & TNCB & TDN & $\mathrm{NH}_{4-\mathrm{N}}$ & $\mathrm{NO}_{3}-\mathrm{N}$ & TDP & $\mathrm{PO}_{4}-\mathrm{P}$ & Chl-a \\
\hline \multirow{5}{*}{ S1 } & Min. & 6.10 & 7.20 & 0.20 & 0.50 & 0.64 & 2.00 & 9.50 & 0.80 & 90 & 0.00 & 0.62 & 0.00 & 0.48 & 0.00 & 0.00 & 0.00 \\
\hline & Max. & 8.90 & 19.30 & 1.30 & 3.80 & 4.62 & 140 & 1185.33 & 25 & 308 & 92,000 & 4.53 & 0.57 & 4.35 & 0.14 & 0.07 & 7.90 \\
\hline & Mean & 7.59 & 11.10 & 0.56 & 1.61 & 1.99 & 23.57 & 163.36 & 12.99 & 163.86 & 6091.61 & 1.90 & 0.04 & 1.76 & 0.01 & 0.01 & 0.67 \\
\hline & SD & 0.58 & 2.20 & 0.24 & 0.61 & 0.64 & 23.02 & 179.35 & 7.56 & 43.03 & $19,617.33$ & 0.63 & 0.08 & 0.62 & 0.02 & 0.01 & 1.09 \\
\hline & CV & 7.58 & 19.85 & 42.95 & 38.13 & 32.22 & 97.68 & 109.79 & 58.17 & 26.26 & 322.04 & 33.22 & 175.83 & 35.46 & 122.39 & 167.86 & 162.08 \\
\hline \multirow{5}{*}{ S2 } & Min. & 6.70 & 6.40 & 0.20 & 0.60 & 0.57 & 2.00 & 14.46 & 1.40 & 6 & 0.00 & 0.55 & 0.00 & 0.37 & 0.00 & 0.00 & 0.00 \\
\hline & Max. & 8.60 & 19.20 & 4.30 & 5.40 & 3.86 & 140 & 644 & 26.50 & 520 & 240,000 & 3.79 & 1.69 & 3.41 & 0.12 & 0.11 & 6.90 \\
\hline & Mean & 7.57 & 10.89 & 0.99 & 2.32 & 1.98 & 32.24 & 100.71 & 14.45 & 198.46 & 6138.71 & 1.89 & 0.12 & 1.60 & 0.02 & 0.01 & 1.31 \\
\hline & SD & 0.41 & 2.39 & 0.67 & 1.06 & 0.63 & 23.73 & 99 & 7.94 & 52.68 & $28,947.48$ & 0.62 & 0.25 & 0.58 & 0.02 & 0.02 & 1.24 \\
\hline & CV & 5.39 & 21.93 & 66.90 & 45.73 & 31.78 & 73.60 & 98.30 & 54.93 & 26.54 & 471.56 & 33.08 & 205.96 & 35.97 & 87.10 & 169.35 & 94.69 \\
\hline \multirow{5}{*}{ S3 } & Min. & 6.90 & 8.70 & 0.50 & 1.20 & 1.00 & 9.00 & 10.99 & -0.50 & 122 & 6 & 0.81 & 0.01 & 0.02 & 0.00 & 0.00 & 0.40 \\
\hline & Max. & 8.20 & 15.70 & 2.90 & 8.40 & 5.19 & 266 & 408.56 & 26.90 & 337 & 140,000 & 3.54 & 0.32 & 2.85 & 0.17 & 0.12 & 30.20 \\
\hline & Mean & 7.69 & 11.68 & 1.15 & 3.78 & 2.26 & 43.83 & 86.53 & 13.86 & 231.19 & 3262.68 & 2.08 & 0.05 & 1.55 & 0.02 & 0.01 & 6.82 \\
\hline & SD & 0.23 & 2.06 & 0.48 & 1.30 & 0.61 & 44.02 & 68.09 & 8.46 & 46.20 & $15,677.68$ & 0.58 & 0.05 & 0.61 & 0.03 & 0.02 & 5.59 \\
\hline & $\mathrm{CV}$ & 2.97 & 17.67 & 41.68 & 34.45 & 27.13 & 100.44 & 78.69 & 61.02 & 19.98 & 480.52 & 28.03 & 93.82 & 39.74 & 112.84 & 172.74 & 81.94 \\
\hline \multirow{5}{*}{ S4 } & Min. & 7.10 & 6.20 & 0.30 & 0.90 & 0.35 & 3.00 & 4.44 & 0.00 & 103 & 2 & 0.34 & 0.00 & 0.11 & 0.00 & 0.00 & 0.10 \\
\hline & Max. & 9.00 & 16.50 & 2.60 & 18.70 & 2.94 & 661 & 569.25 & 30.70 & 300 & 40,000 & 2.43 & 0.43 & 2.25 & 0.13 & 0.12 & 37.50 \\
\hline & Mean & 8.07 & 10.65 & 0.85 & 3.50 & 1.56 & 39.96 & 101.09 & 14.64 & 204.93 & 1540.23 & 1.42 & 0.04 & 1.13 & 0.02 & 0.01 & 5.37 \\
\hline & SD & 0.37 & 2.55 & 0.53 & 1.98 & 0.60 & 79.64 & 101.45 & 9.41 & 44.44 & 4844.51 & 0.54 & 0.08 & 0.54 & 0.02 & 0.02 & 6.73 \\
\hline & $\mathrm{CV}$ & 4.63 & 23.97 & 62.51 & 56.57 & 38.41 & 199.28 & 100.36 & 64.32 & 21.69 & 314.53 & 38.03 & 175.59 & 47.46 & 125.30 & 194.79 & 125.25 \\
\hline
\end{tabular}

$\mathrm{S}=$ Site, Min. = Minimum, Max. = Maximum, $\mathrm{SD}=$ Standard deviation, $\mathrm{CV}=$ Coefficient of variance, $\mathrm{DO}=$ Dissolved oxygen, $\mathrm{BOD}=$ Biological oxygen demand, $\mathrm{COD}=\mathrm{Chemical}$ oxygen demand $\mathrm{TN}=$ Total nitrogen, $\mathrm{TP}=$ Total phosphorus, TN:TP $=$ Ratios of total nitrogen and total phosphorus, Temp. = Temperature, EC = Electrical conductivity, $\mathrm{TNCB}=\mathrm{Total}$ number of Coliform bacteria, $\mathrm{TDN}=$ Total dissolved nitrogen, $\mathrm{NH}_{4}-\mathrm{N}=$ Ammonia nitrogen, $\mathrm{NO}_{3}-\mathrm{N}=$ Nitrate nitrogen, TDP = Total dissolved phosphorus, $\mathrm{PO}_{4}-\mathrm{P}=\mathrm{Phosphate}$ phosphorus, Chl-a = Chlorophyll-a. 

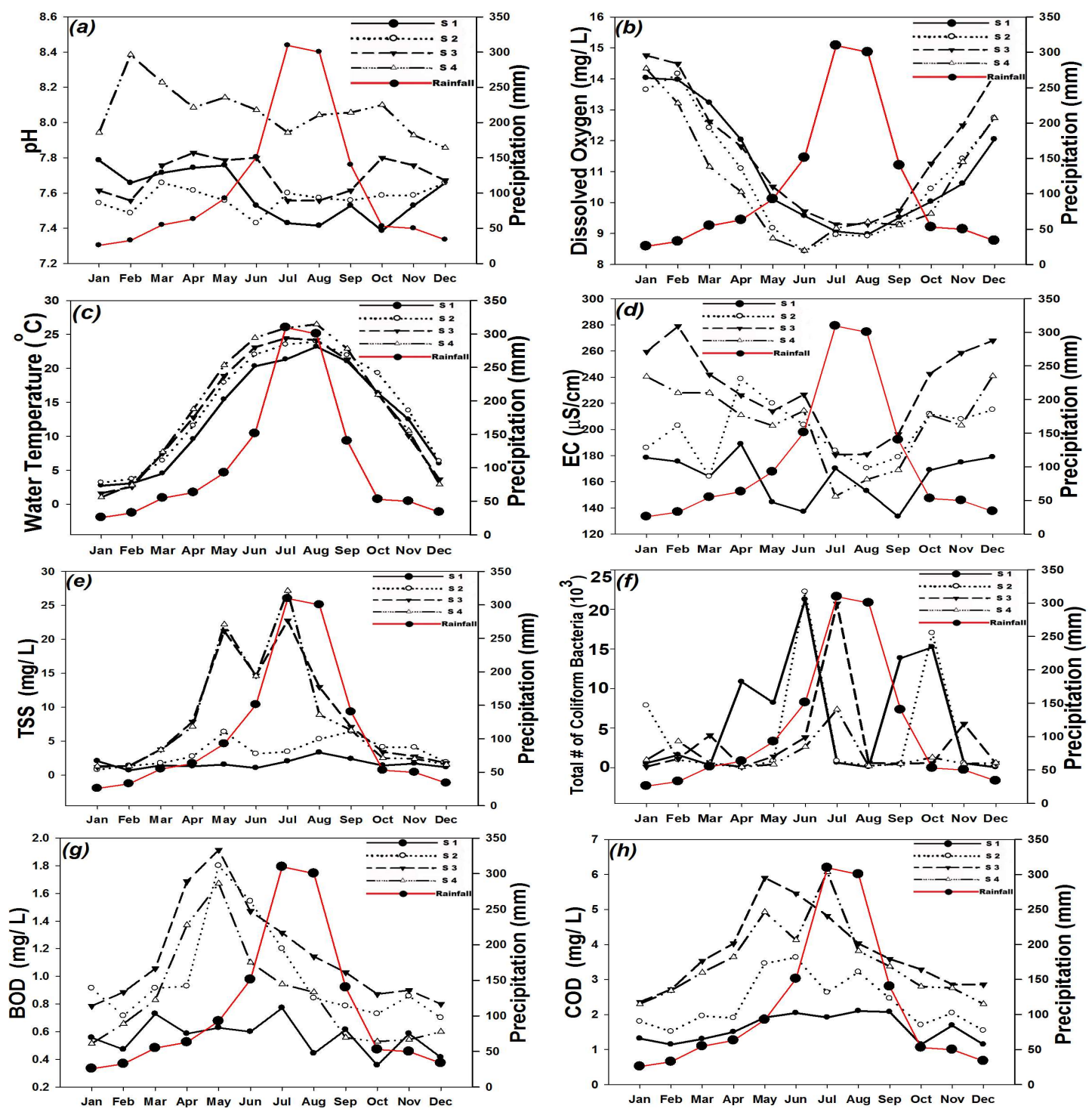

Figure 2. Seasonal change in physiochemical water quality parameters at four sites in Bouchung Stream during 2008-2014. (Values obtained from monthly means). (a) pH, (b) Dossolved oxygen, (c) Water temperature, (d) Electrical conductivy, (e) Total suspended solids, (f) (Total numbero coliform bacteria, (g) Biological oxygen demand, (h) Chemical oxygen demand.

The seasonal values of nutrient contributing factors, mainly comprising of nitrogen, phosphorus, and their allied chemical species, were significantly affected by the summer monsoon precipitation pattern (Figure 3). The summer monsoon rainfall showed almost no effect on the seasonal variations of nitrogen regime, except adding it up in the downstream region. Total Nitrogen, $\mathrm{TDN}$, and $\mathrm{NO}_{3}-\mathrm{N}$ showed reciprocal seasonal changes during summer monsoon. On the other hand, TP showed spatial variations. In headwater zones, average seasonal change appeared nominal and less affected by seasonal rainfall due to none-existing agricultural pastures. However, as the stream stretched downwards, it showed huge deviations in TP levels, with pronounced changes approximating with the increased rainfall during the summer monsoon. It showed that agricultural runoff currents have the potential to increase phosphorus levels downstream. Total dissolved phosphorus showed less visible seasonal changes, displaying a shadowed peak after the summer monsoon rainfall that denoted the agricultural runoff effect. $\mathrm{PO}_{4}-\mathrm{P}$ was parallel throughout the years in headwater sites, but showed conspicuous variations at downstream waters. The highest average $\mathrm{PO}_{4}$-P values $(43.83 \pm 44.02 \mu \mathrm{g} / \mathrm{L})$ were recorded during the summer monsoon rainfall. The outcome of 
average sestonic CHL-a concentration showed almost no seasonal change in headwater zones, but a gradual increase in downstream reciprocating with TP. The CHL-a concentration appeared diluted with summer monsoon, and showed a slight possibility of eutrophication in proceeding months. Large change in nutrient contributing factors, starting at S3 and downstream, reflected the effect of urban land-use, as well as intensive agricultural pasture runoff that constituted approximately $58 \%$ of the surrounding area. Overall, it could conclude that headwater zones were minimally influenced, while downstream zones seemed susceptible to the effluents originating from the WWTP, industrial effluents, and intensive agricultural farming in the area [38].
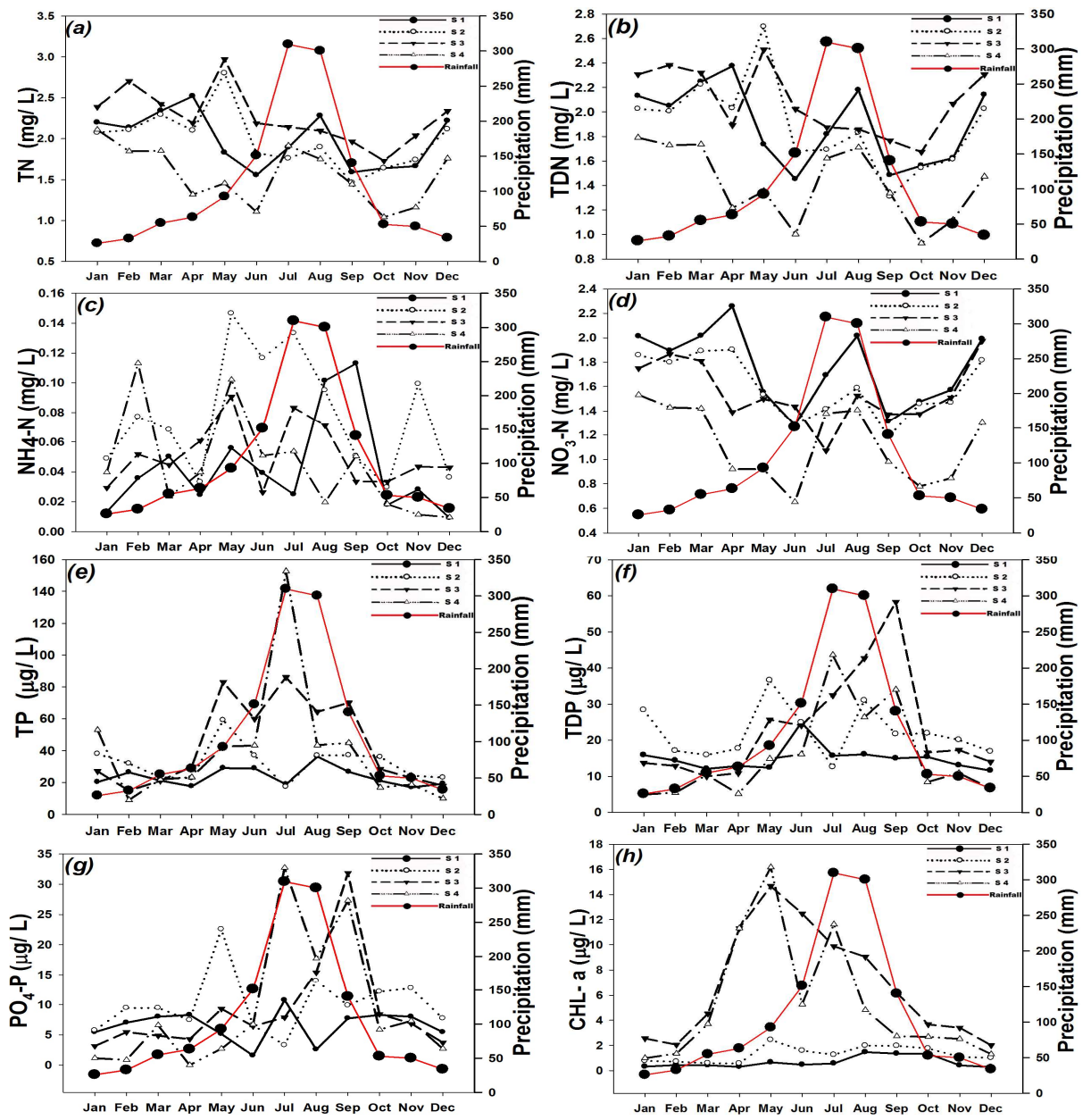

Figure 3. Seasonal variation in nutrient regime and chlorophyll-a at four sites in Bouchung Stream during 2008-2014. (Values obtained from monthly means). (a) Total nitrogen, (b) Total dissolved nitrogen, (c) Ammonia nitrogen, (d) Nitrate nitrogen, (e) Total phosphorus, (f) Total dissolved phosphorus, (g) Phosphate phosphorus, (h) Chlorophyll-a.

\subsection{Inter-Annual Variations in Water Chemistry}

The annual rainfall that mainly concentrated during the monsoon periods resulted in the inter-annual water quality fluctuations (Figure 4). The annual rainfall data helped in designating the years as either wet or dry; 2010-2012 were the wet years in the stream watershed area, while 2011 was wettest year with maximum rainfall. The water quality parameters varied in relation to wet and dry years. The annual mean values of $\mathrm{pH}$ were lower in dry years, but increased during wet years. Dissolved oxygen, Temp, EC, and TSS annual mean variations did not change during wet and dry years. However, TNCB showed a great variation during wet and dry years. During dry years, bacterial count was higher, whereas it increasingly dropped in the proceeding dry years. It confirmed 
that there were more chances of water borne diseases during the dry years [62]. Chemical oxygen demand showed no major changes during these years. On the other hand, BOD showed a very fine, but steep decline in annual mean values during 2008-2014, except in 2012, which showed a slight increase after the wet year. Similarly, the annual rainfall mainly influenced the inter-annual trends of nutrient contributing parameters (Figure 5). The annual mean value of TN was the lowest during 2009 (dry year), but the highest in 2012, which was post-wet year, and again showed a decline in the proceeding dry years. Similarly, TDN showed a sturdy increase from 2009 to 2012 that was due to higher annual rainfall. Except $\mathrm{NH}_{4}-\mathrm{N}$, all nitrogen species were affected by flood years. Like TN, TP also showed a decrease during 2008-2009, which was a dry span, but was affected by wet years by carrying more $\mathrm{P}$ from the agricultural pastures. The mean annual rate of TDP was dispersed around $20 \mu \mathrm{g} / \mathrm{L}$, but appeared influenced by wet years. The $\mathrm{PO}_{4}-\mathrm{P}$ showed many outlying values, but the annual mean values showed a slight decrease in the first two dry years with higher annual means recorded during the wet years, and then was similar during the ensuing dry years. Sestonic CHL-a annual mean values started dropping during 2008-2010 which were higher during the dry years, and then showed approximation in the wet years. This type of variation in the inter-annual means of nutrient contributing factors and sestonic CHL-a reflected the intensive agricultural activities downstream, as well as urban land-use $[7,38,63]$.
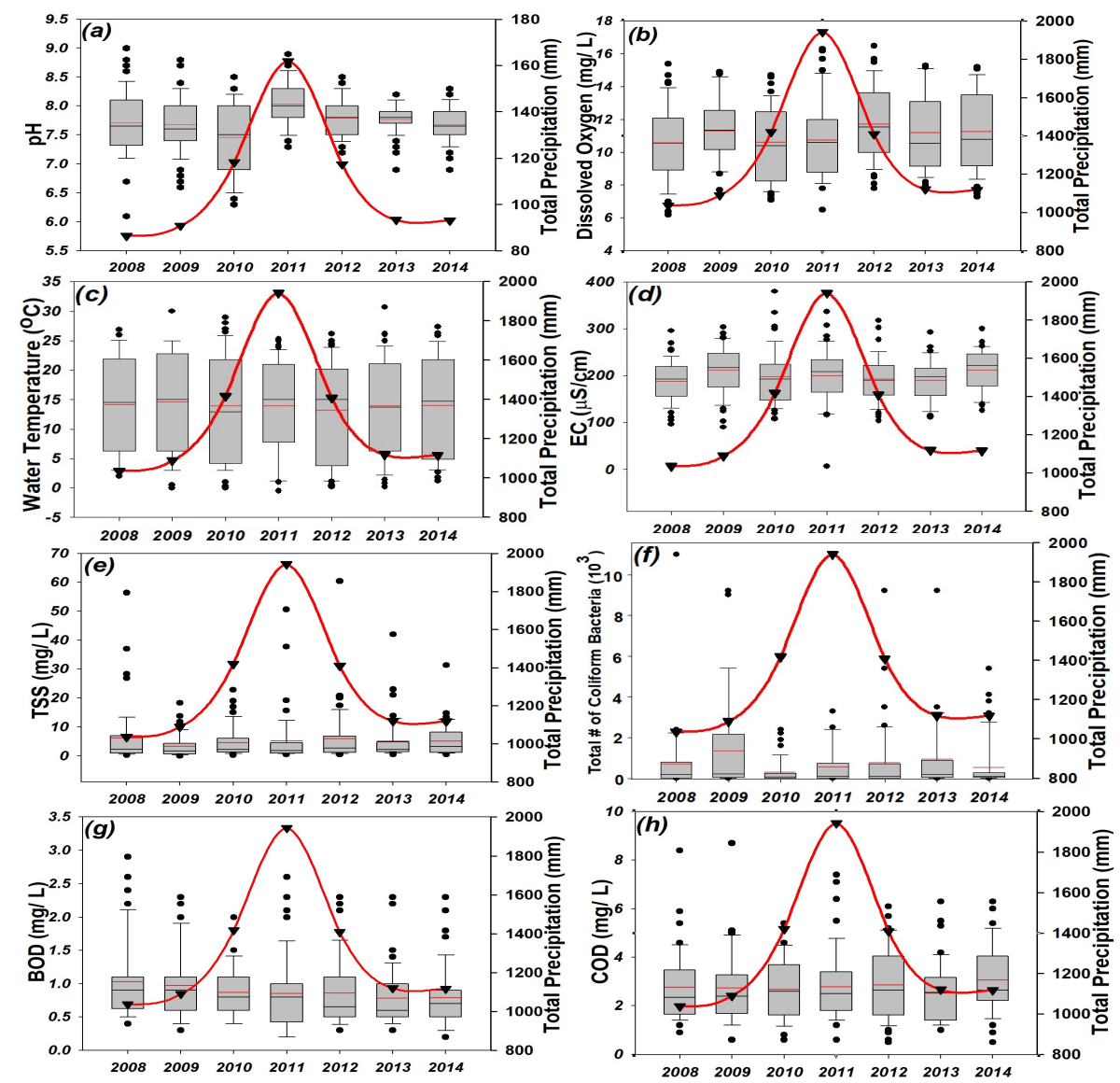

Figure 4. Annual trend in physicochemical water quality parameters in Bouchung Stream during 2008-2014. (Red line in box indicates annual mean and red curve shows annual precipitation in millimeter)). (a) pH, (b) Dossolved oxygen, (c) Water temperature, (d) Electrical conductivy, (e) Total suspended solids, (f) (Total numbero coliform bacteria, (g) Biological oxygen demand, (h) Chemical oxygen demand. 

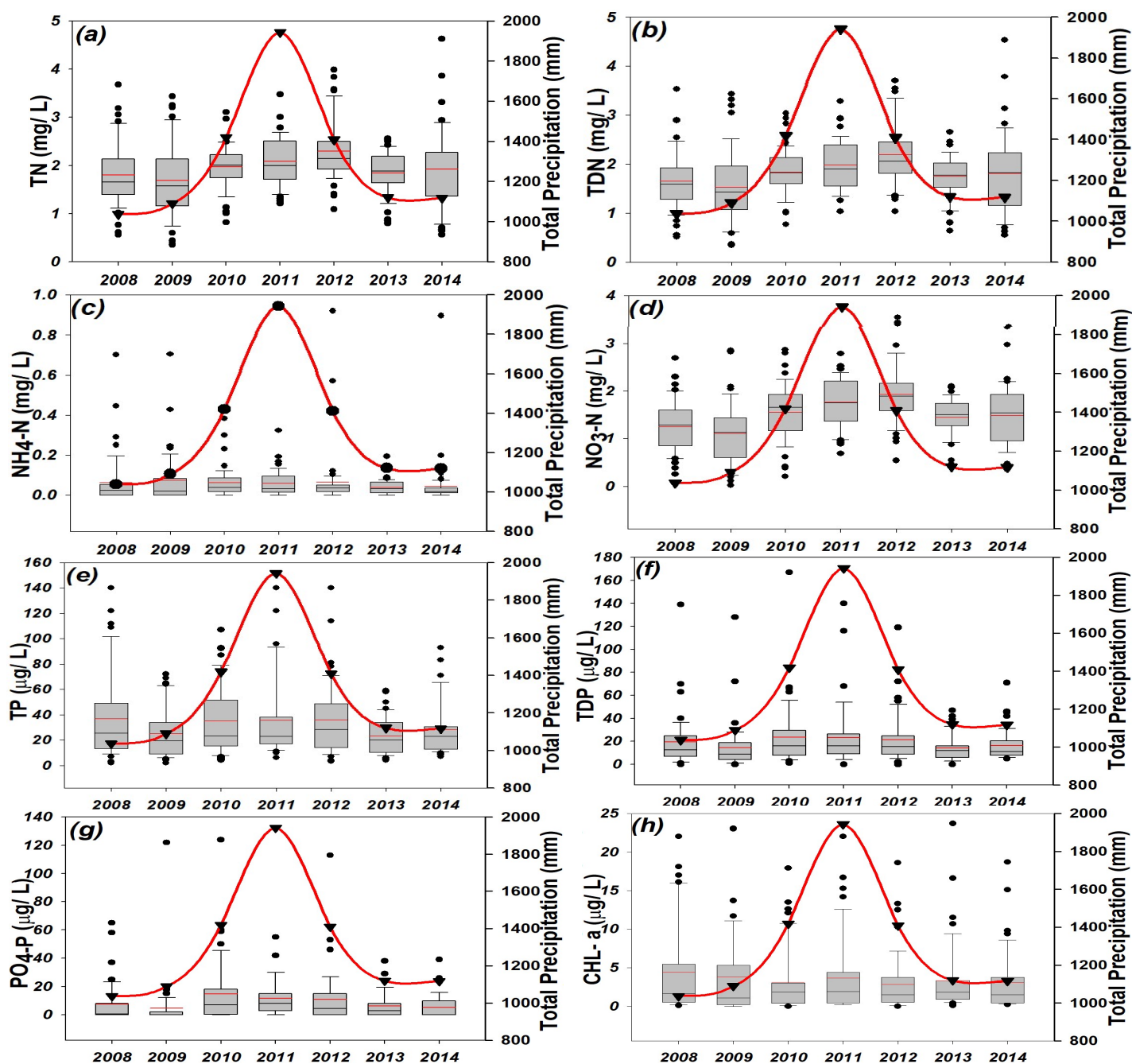

Figure 5. Annual variation in nutrient contributing quality parameters in Bouchung Stream from 2008-2014. (Red line in box indicates annual mean and red curve shows annual precipitation in millimeter). (a) Total nitrogen, (b) Total dissolved nitrogen, (c) Ammonia nitrogen, (d) Nitrate nitrogen, (e) Total phosphorus, (f) Total dissolved phosphorus, (g) Phosphate phosphorus, (h) Chlorophyll-a.

\subsection{Empirical Modelling on Chlorophyll and Nutrient Contributing Factors}

The regression relationship between log-transformed CHL-a, TN, TP, TN:TP, and empirical linear models of CHL-a showed non-significant relation with $\mathrm{TN}\left(R^{2}=0.0001\right)$. On the contrary, variation of CHL-a linked up to $17 \%$ with TP $\left(R^{2}=0.17\right)$ and showed a positive relation with TP (Figure 6). Also, the change in CHL-a accounted for $15 \%$ with TN:TP $\left(R^{2}=0.159\right)$ and showed a negative relation with TN:TP ambient ratios in the present study. It showed an equal contribution (7\%) of N and P in TN:TP ambient ratios in the ambient water as well. 

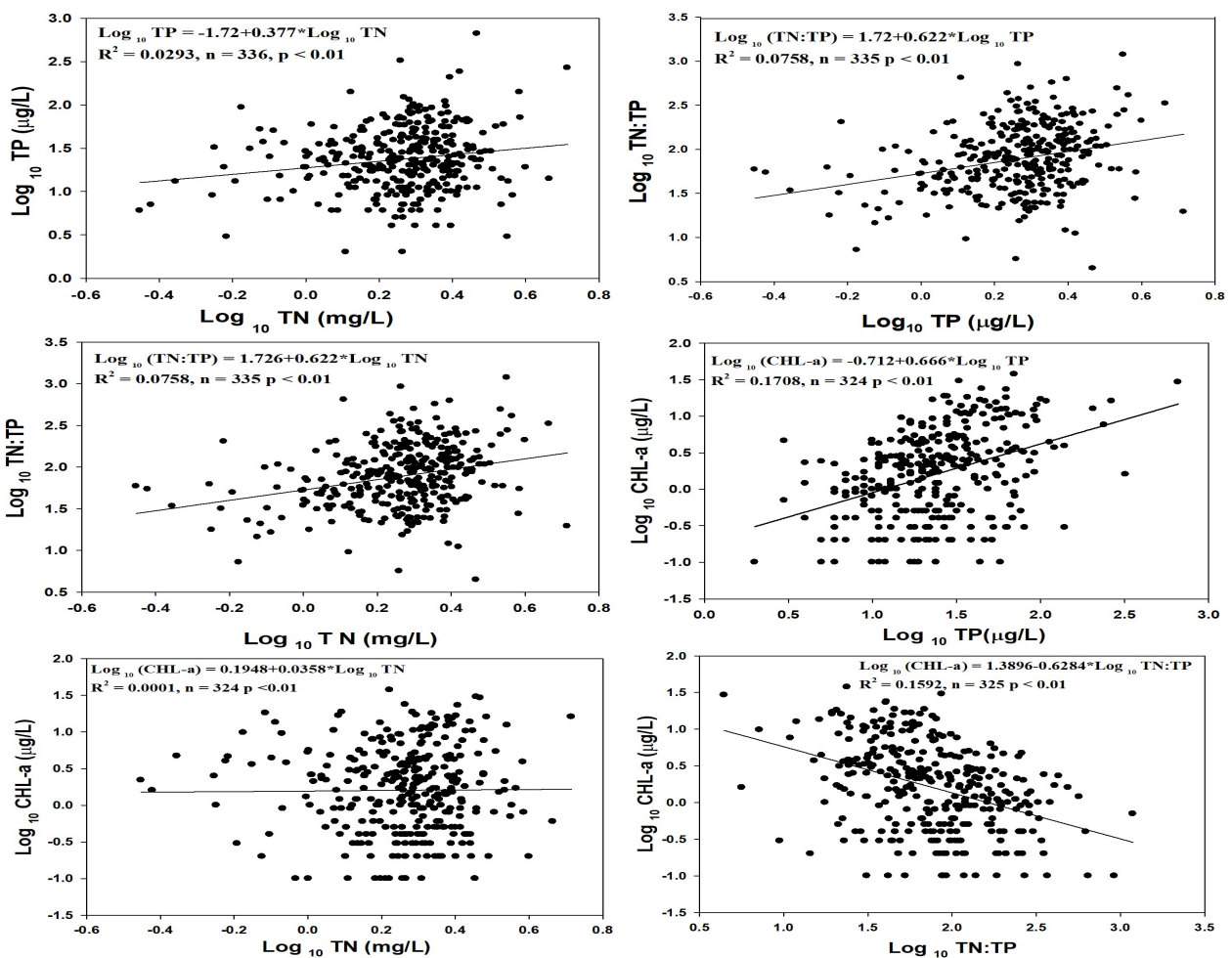

Figure 6. Regression analysis on the log-transformed nutrient contributing factors in Bouchung stream during 2008-2014. (The nutrient factors include total nitrogen, total phosphorus, their ambient ratios and their relationship with chlorophyll-a).

Therefore, it could be argued that the primary nutrient which was subsidizing the bulk share in the primary productivity (sestonic CHL-a) was phosphorus and originated from the agricultural paddocks in the area, while the nitrogen might be ample to fuel sustainable algal growth. Hitherto conducted numerous studies on streams $[7,64-66]$ suggested that other primary factors instrumental as limiting factors in the stream ecosystem were turbidity and short water residence time leading to light limitation. Similar results were pointed out in the Yeongsan River (South Korea) by Song et al. [67]. However, such generalized phenomena was only evident during July-August, due to higher floods caused by intensive rainfall. Therefore, the TN:TP ratio could be designated as the vital regulatory factor in primary productivity. Further, it was supported by the earlier findings of Downing and MeCauly [68] who related TN:TP ratio more depended upon P than N under P limitation circumstances. But the non-significant relation of TN:TP ratios with $\mathrm{N}$ was due to lower variation as well as higher ambient nitrogen concentration compared to phosphorus [63].

\subsection{Correlation of Water Chemistry Parameters}

The WPI showed a very strong positive correlation $(r<0.70)$ with IBI, whereas TSS showed strong positive correlation with TP and COD (Figure 7). Sestonic CHL-a indicated strong and moderately strong positive relationships with COD, BOD, and TSS, respectively. TN:TP ambient ratios showed a moderately negative relationship with $\mathrm{TP}$, and very weak negative relationship with $\mathrm{TN}$. However, TN and other allied chemical species showed moderately strong positive relationships with each other, indicating industrial effluents were the leading factors in the nitrogen inflow to the watershed. Similar was the case with TP and other allied chemical species. However, both the indices (i.e., WPI and IBI) showed very low relationships with water chemistry factors, except TP which showed a slightly higher, yet still very weak relationship with both indices. 


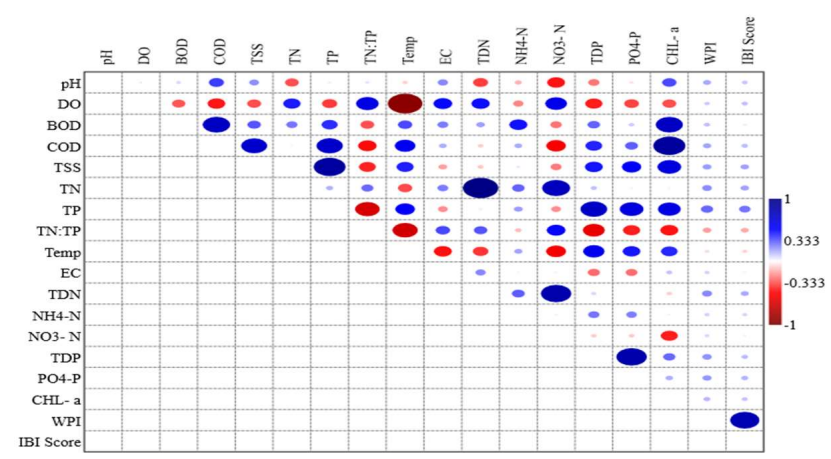

Figure 7. Correlation analysis of the water chemistry factors and index of biotic integrity (IBI) in Bouchung Stream during 2008-2014. (Blue indicates the strength of positive, while red indicates the strength of negative correlation between the water chemistry factors).

\subsection{Chemical Health Evaluation Based on Modified Multi-Metric Water Pollution Index (WPI)}

A modified multi-metric index for water pollution assessment was applied to diagnose the chemical health status of the stream and to obtain scores, which led to the categorization of the stream according to chemical health (Table 1). It is composed of seven metrics $\left(\mathrm{M}_{1}-\mathrm{M}_{7}\right)$ and constituting four major categories viz. nutrient regime (TN, TP and TN:TP), organic matter (BOD), ionic contents and solids (TSS and EC), and primary production indicator (CHL-a). Major nutrient contributing factors (i.e., TN, TP and TN:TP mass ratios) were key determinants of the water quality and eutrophication $[7,69,70]$.

The chemical criteria of ambient TN metric were classified as oligotrophic ( $3 \mathrm{mg} / \mathrm{L})$, mesotrophic $(1.5-3 \mathrm{mg} / \mathrm{L})$, and eutrophic $(>3 \mathrm{mg} / \mathrm{L})$ respectively. All sites categorized as mesotrophic had a TN level ranging from $1.5-3 \mathrm{mg} / \mathrm{L}$. S3 showed the highest mean TN level $(2.26 \mathrm{mg} / \mathrm{L})$. Similarly, according to TP level criteria $(<30,30-100$ and $>100 \mu \mathrm{g} / \mathrm{L})$, S1 was oligotrophic (23.57) and the rest of the sites were mesotrophic, while S3 showed the highest mean TP (43.83). TN:TP ambient ratios showed oligotrophic states at all sites showing higher values. Previous studies have shown that TN:TP ratio in ambient water was an indirect indicator of nutrient limitation for primary productivity [71,72], and if lower, showed higher nutrient pollutants leading to eutrophication [21]. Mean concentration of sestonic CHL-a confirmed the assessment of S1 and S2 as oligotrophic, having CHL-a levels lower than $3 \mu \mathrm{g} / \mathrm{L}$. However, at S3 and S4, they showed a five times increase under the mesotrophic conditions approximating the levels of TP in downstream, but less primary productivity at S2. Similarly, it was also in line with the values obtained from TN:TP ratios in the stream that again depressed the notion of eutrophication in downstream sites. Meanwhile, biological oxygen demand levels were maximized at $\mathrm{S} 3(1.15 \mathrm{mg} / \mathrm{L})$.

In the case of TSS and EC, S1 was in an oligotrophic state, but S2 showed an increase indicating it as a recipient of agricultural runoff. Total suspended solids were the highest at $\mathrm{S} 4(12.86 \mathrm{mg} / \mathrm{L})$, approximating with the values obtained for EC $(204.92 \mu \mathrm{S} / \mathrm{cm})$, which was an indication of increasing nutrient pollution in imminent years in the downstream water of Bouchung Stream. The final scores indicated that $\mathrm{S} 1$ could be chemically categorized as excellent, with a score of 33; S2 as good with a score of 29; and S3 and S4 as fair, each having a score of 23 (Figure 8). These results showed a starting point of chemical health deterioration in the downstream waters that was mainly due to agricultural runoff waters, especially during floods caused by summer monsoons. It also confirms that this results in sedimentation in the downstream regions by causing higher turbidity. A major share was contributed by the WWTP at S3, which was also confirmed by the results of the WPI. Earlier studies opulently supported the degradation of downstream water chemical health [41,73].

\subsection{Biological Health Evaluation Based on Modified Multi-Metric Index of Biotic Integrity}

The biological health evaluation of the stream was carried out after the application of modified multi-metric index of biotic integrity $\left(\mathrm{IBI}_{\mathrm{KW}}\right)$ model (Table 2$)$. The eight metrics $\left(\mathrm{M}_{1}-\mathrm{M}_{8}\right)$ classified into 
three main categories viz. species richness and composition, trophic composition, and fish abundances and health condition. Native and benthic species indicated that the biotic integrity was near to excellent, but sensitive species were higher at the S1 and S2 that apparently would have migrated upstream due to intensifying pollutants downstream. The proportion of tolerant species was lower at S1, but higher at S2, followed by S4 and S3, which indicated the onset of nutrient pollution as confirmed by the WPI model final scores in this stream. Surprisingly, omnivore species at all sites approximated with tolerant species in the same manner, although the scoring criteria was different. The obtained values for native insectivore fish species showed that S1 and S3 had the most number of native species, whereas S3 and $\mathrm{S} 4$ were home to almost half of the native species. The number of native individuals showed that the $\mathrm{S} 4$ had the least number of native individuals that showed a major modification in fish composition from headwaters down the line. The relative abundance (RA, \%), total number of individuals (TNI), as well as number of individuals sampled at each site along with their tolerance and trophic guilds, showed a prodigious disparity (Table 4). It was too hard to enlist all 64 species; therefore, some of them were dropped having a relative abundance lower than $0.10 \%$.

Biological stream health has started dwindling downstream due to deteriorating water quality and the indicators included the decreasing sensitive species as well as increasing tolerant species downstream. The decline in total number of individuals sampled spatially, as well as temporally, was another corroboration of the rigorousness of impending decline of biological health. The lower scores obtained by metrics in the downstream sites were due to the degrading water quality attributed to the WWTP and the agricultural runoff $[49,74,75]$. The IBI final score values steered to categorized the S1 as excellent, S2 as fair, and S3 and S4 designated as good (Figure 8). Moreover, the community structure mainly based on the fish compositions of tolerance and trophic guilds (Figure 9) showed that the dominant trophic guilds were the native insectivores, followed by omnivores, whereas the higher relative abundance in tolerance guild was composed of intermediate, followed by tolerant species clearly indicating the tolerant species on the rise due to degrading water quality. Zacco platypus is a tolerant species and the most dominant fish species (27.35\%), showing a spatial abundance followed by Zacco koreanus (11.62\%), which is a sensitive species and displayed a spatial decline. The results are line with the previous studies [7].

\subsection{Responses of Trophic and Tolerant Guilds to Water Chemistry}

Where it revealed an undeviating relationship between the scores of modified multi-metric indices of water pollution and biotic integrity $\left(R^{2}=0.90, \mathrm{~F}=510.41, p<0.0001\right)$ (Figure 10), it also showed that the relative abundance of trophic and tolerance guilds was affected by water quality factors, although some appeared to be indecisive on fish distribution (Figure 11). The results of intermediate species (IS), tolerant species (TS), and sensitive species (SS) in relation to ambient BOD, COD, TN, TP, and sestonic CHL-a showed when BOD, COD, and TN were lower, and IS and TS showed a wide distribution exhibiting a direct functional relationship with the changing water chemistry. However, SS showed varied distribution along the gradient with respect to the BOD, COD, TN, TP, and sestonic CHL-a, which showed SS more sensitive to the changing water chemistry. TP and sestonic CHL-a level were less influential in controlling IS and TS abundance along the stream region. These results were in line with previous findings as well $[38,49]$. Omnivores showed no distinct effect of COD and TN but linear distribution was observed in case of BOD, TP, EC, and sestonic CHL-a, which showed a small response that water pollution affected the distribution of omnivores (Figure 12). Instead, carnivores showed BOD, COD, and EC affected their distribution while TN, TP, and sestonic CHL-a had a direct linear relation on carnivore abundance. The native insectivores showed also direct linear relationship with BOD, COD, TN, TP, EC, and sestonic CHL-a along the stream gradient. The IBI showed an indistinct influence of COD, TN, TP, TN:TP, and sestonic CHL-a (log-transformed) which showed that these water quality parameters had an inadequate role in the fish distribution. However, the BOD, TSS, and EC had a little effect (less than 10\%) on the overall fish distribution estimated IBI (Figure 13). Earlier regional studies supported these results as well $[6,22]$. 
Table 4. Fish fauna, various guilds and individual number of fish sampled from Bouchung stream along with their relative abundance (RA) during $2008-2014$.

\begin{tabular}{|c|c|c|c|c|c|c|c|c|c|}
\hline \multirow{2}{*}{ Species } & \multicolumn{3}{|c|}{ Type of Fish Guild } & \multicolumn{4}{|c|}{ Sampling Sites } & \multirow{2}{*}{ TNI } & \multirow{2}{*}{ RA (\%) } \\
\hline & Tol. G. & Tro. G. & Hab. G. & S1 & S2 & S3 & S4 & & \\
\hline Zacco platypus & TS & $\mathrm{O}$ & - & 67 & 1137 & 471 & 673 & 2348 & 27.35 \\
\hline Zacco koreanus & SS & I & & 788 & 14 & 169 & 27 & 998 & 11.62 \\
\hline Rhinogobius brunneus & IS & I & RB & 23 & 53 & 403 & 189 & 668 & 7.78 \\
\hline Zacco temminckii & SS & I & - & 445 & 0 & 71 & 19 & 535 & 6.23 \\
\hline Pseudogobio esocinus & IS & I & - & 9 & 358 & 79 & 84 & 530 & 6.17 \\
\hline Hamibarbus longirostris & IS & I & - & 315 & 112 & 43 & 8 & 478 & 5.57 \\
\hline Acheilognathus lanceolatus & IS & $\mathrm{O}$ & - & 5 & 59 & 238 & 42 & 344 & 4.01 \\
\hline Acheilognathus koreensis & IS & $\mathrm{O}$ & - & 3 & 8 & 265 & 46 & 322 & 3.75 \\
\hline Pungtungia herzi & IS & I & - & 21 & 78 & 114 & 38 & 251 & 2.92 \\
\hline Microphysogobio yaluensis & IS & $\mathrm{O}$ & RB & 4 & 56 & 163 & 22 & 245 & 2.85 \\
\hline Odontobutis platycephala & SS & C & - & 134 & 10 & 15 & 42 & 201 & 2.34 \\
\hline Coreoleuciscus splendidus & SS & I & RB & 0 & 0 & 130 & 27 & 157 & 1.83 \\
\hline Iksookimia koreensis & IS & I & RB & 17 & 13 & 85 & 36 & 151 & 1.76 \\
\hline Odontobutis interrupta & IS & C & - & 58 & 45 & 23 & 3 & 129 & 1.50 \\
\hline Opsarichthys uncirostris amurensis & TS & C & - & 0 & 99 & 11 & 6 & 116 & 1.35 \\
\hline Acheilognathus yamatsuatea & IS & $\mathrm{O}$ & - & 0 & 5 & 9 & 77 & 91 & 1.06 \\
\hline Gobiobotia brevibarba & SS & I & RB & 0 & 6 & 73 & 0 & 79 & 0.92 \\
\hline Micropterus salmoides & TS & $\mathrm{C}$ & - & 2 & 52 & 18 & 4 & 76 & 0.89 \\
\hline Cobitis lutheri & IS & I & - & 0 & 76 & 0 & 0 & 76 & 0.89 \\
\hline Sarcocheilichthys variegatus wakiyae & SS & I & - & 0 & 1 & 10 & 63 & 74 & 0.86 \\
\hline Squalidus chankaensis tsuchigae & IS & $\mathrm{O}$ & - & 0 & 10 & 10 & 50 & 70 & 0.82 \\
\hline Rhynchocypris oxycephalus & SS & I & - & 64 & 0 & 1 & 0 & 65 & 0.76 \\
\hline Tridentiger brevispinis & IS & I & RB & 0 & 1 & 5 & 36 & 42 & 0.49 \\
\hline Pseudopungtungia nigra & SS & I & - & 0 & 0 & 0 & 41 & 41 & 0.48 \\
\hline Gasterosteus aculeatus & IS & I & - & 0 & 0 & 40 & 0 & 40 & 0.47 \\
\hline Pseudobagrus koreanus & SS & I & $\mathrm{RB}$ & 0 & 6 & 27 & 5 & 38 & 0.44 \\
\hline Leiocassis nitidus & TS & I & - & 1 & 2 & 29 & 5 & 37 & 0.43 \\
\hline Microphysogobio koreensis & SS & $\mathrm{O}$ & RB & 3 & 15 & 10 & 4 & 32 & 0.37 \\
\hline Squalidus gracilis majimae & SS & I & - & 17 & 0 & 12 & 1 & 30 & 0.35 \\
\hline Misgurnus anguillicaudatus & TS & $\mathrm{O}$ & - & 2 & 16 & 8 & 1 & 27 & 0.31 \\
\hline Pseudorasbora parva & TS & $\mathrm{O}$ & - & 0 & 7 & 0 & 15 & 22 & 0.26 \\
\hline Acheilognathus rhombeus & IS & $\mathrm{O}$ & - & 4 & 1 & 15 & 1 & 21 & 0.24 \\
\hline Pseudobagrus fulvidraco & TS & I & - & 5 & 4 & 11 & 0 & 20 & 0.23 \\
\hline Misgurnus mizolepis & TS & $\mathrm{O}$ & - & 2 & 9 & 7 & 1 & 19 & 0.22 \\
\hline Carassius auratus & TS & $\mathrm{O}$ & - & 0 & 15 & 4 & 0 & 19 & 0.22 \\
\hline Lepomis macrochirus & TS & I & - & 12 & 1 & 0 & 3 & 16 & 0.19 \\
\hline Sarcocheilichthys nigripinnis morii & IS & I & - & 0 & 12 & 0 & 4 & 16 & 0.19 \\
\hline
\end{tabular}


Table 4. Cont.

\begin{tabular}{|c|c|c|c|c|c|c|c|c|c|}
\hline \multirow{2}{*}{ Species } & \multicolumn{3}{|c|}{ Type of Fish Guild } & \multicolumn{4}{|c|}{ Sampling Sites } & \multirow{2}{*}{ TNI } & \multirow{2}{*}{ RA (\%) } \\
\hline & Tol. G. & Tro. G. & Hab. G. & S1 & S2 & S3 & S4 & & \\
\hline Oreochromis niloticus & TS & $\mathrm{O}$ & - & 0 & 4 & 0 & 11 & 15 & 0.17 \\
\hline Hamibarbus labeo & TS & I & - & 0 & 5 & 0 & 9 & 14 & 0.16 \\
\hline Squalidus japonicus coreanus & TS & $\mathrm{O}$ & - & 5 & 0 & 1 & 7 & 13 & 0.15 \\
\hline Koreocobitis naktongensis & SS & $\mathrm{O}$ & RB & 7 & 2 & 2 & 2 & 13 & 0.15 \\
\hline Micropercops swinhonis & IS & $\mathrm{O}$ & - & 0 & 12 & 0 & 0 & 12 & 0.14 \\
\hline Gnathopogon strigatus & IS & I & - & 4 & 6 & 1 & 0 & 11 & 0.13 \\
\hline Takifugu niphobles & IS & I & - & 10 & 0 & 0 & 0 & 10 & 0.12 \\
\hline Total Number of Species & & & & 29 & 39 & 46 & 46 & 64 & \\
\hline Total Number of Individuals & & & & 2034 & 2315 & 2597 & 1640 & 8586 & \\
\hline
\end{tabular}

Tol. G. = Tolerance guild; Tro. G. = Trophic guild; Hab. G. = Habitat guild; TNI = Total number of individuals; TS = Tolerant species; IS = Intermediate species; SS = Sensitive species; $\mathrm{O}=$ Omnivore; $\mathrm{C}=$ Carnivore; $\mathrm{I}$ = Insectivore; $\mathrm{RB}=$ Riffle-benthic species. 

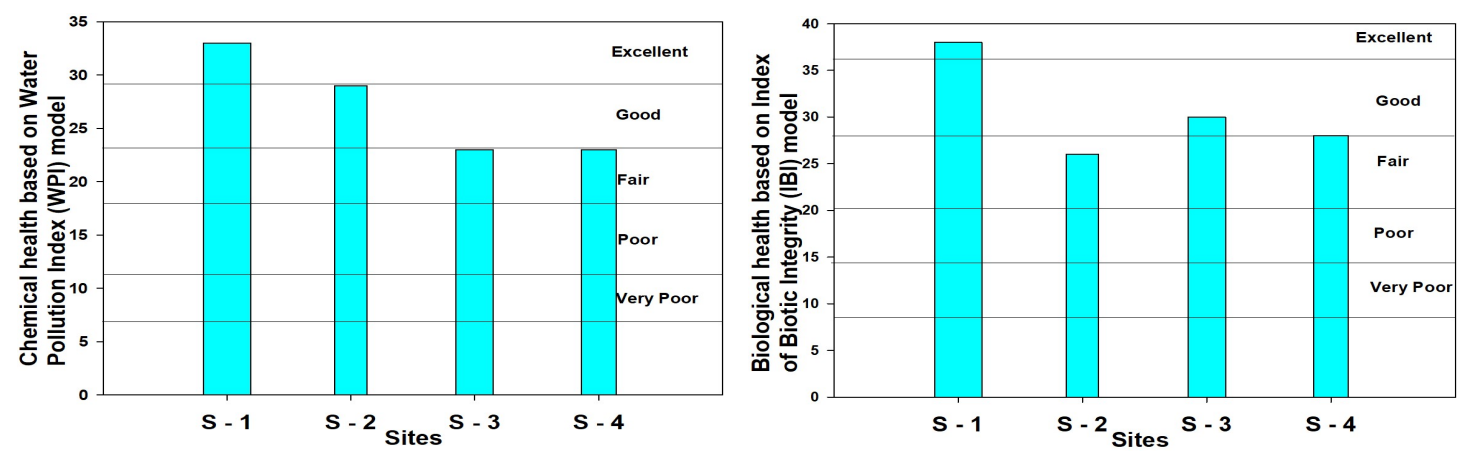

Figure 8. Chemical health based on water pollution index (WPI) and biological health based on index of biotic integrity (IBI) in Bouchung Stream during 2008-2014.
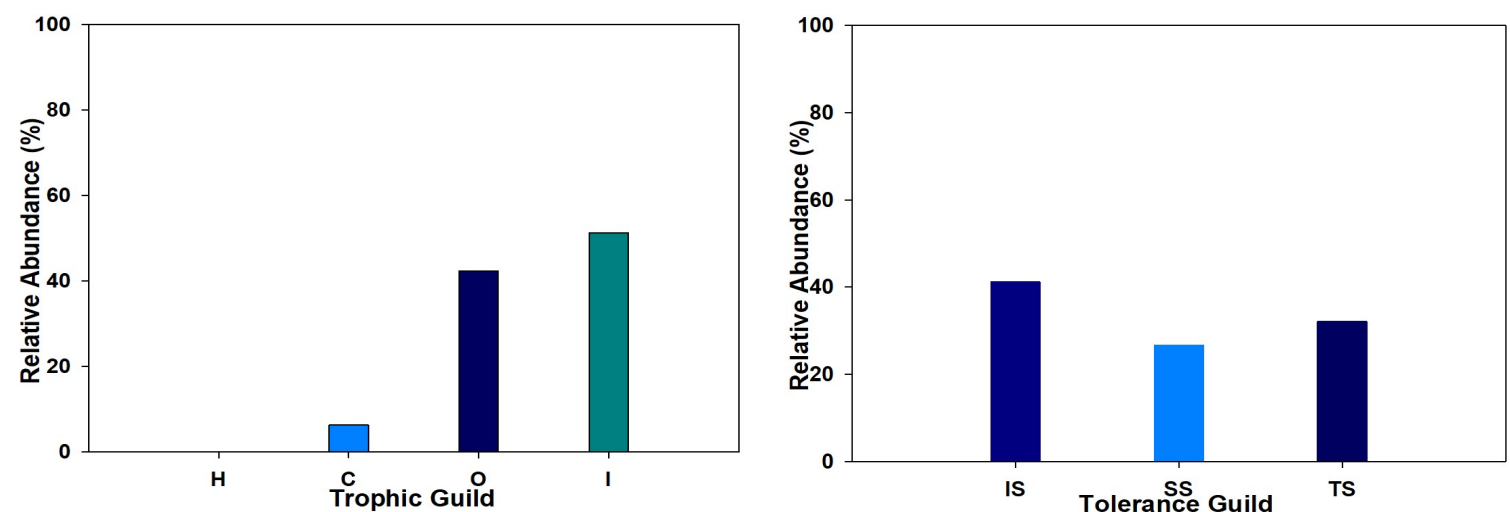

Figure 9. Distribution of trophic guild (herbivores $(\mathrm{H})$ ), carnivores $(\mathrm{C})$, omnivores $(\mathrm{O})$, insectivores $(\mathrm{I})$, and tolerance guild (intermediate (IS), sensitive (SS), and tolerant (TS) in Bouchung Stream during 2008-2014.

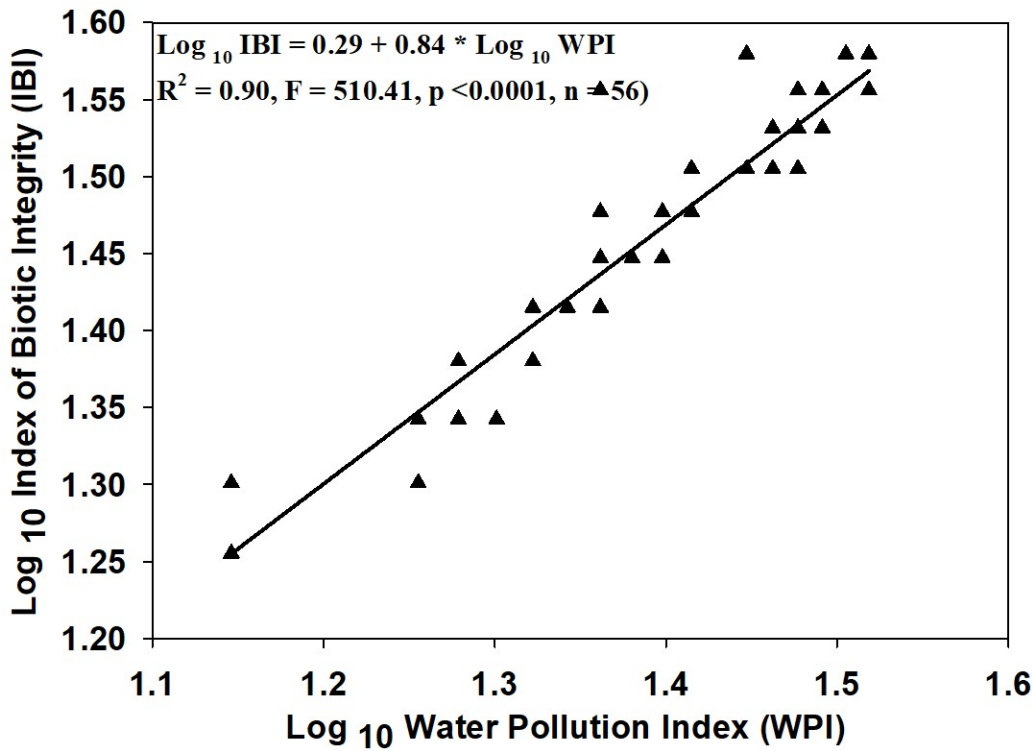

Figure 10. Regression analysis on log-transformed IBI and WPI in Bouchung Stream during 2008-2014. 

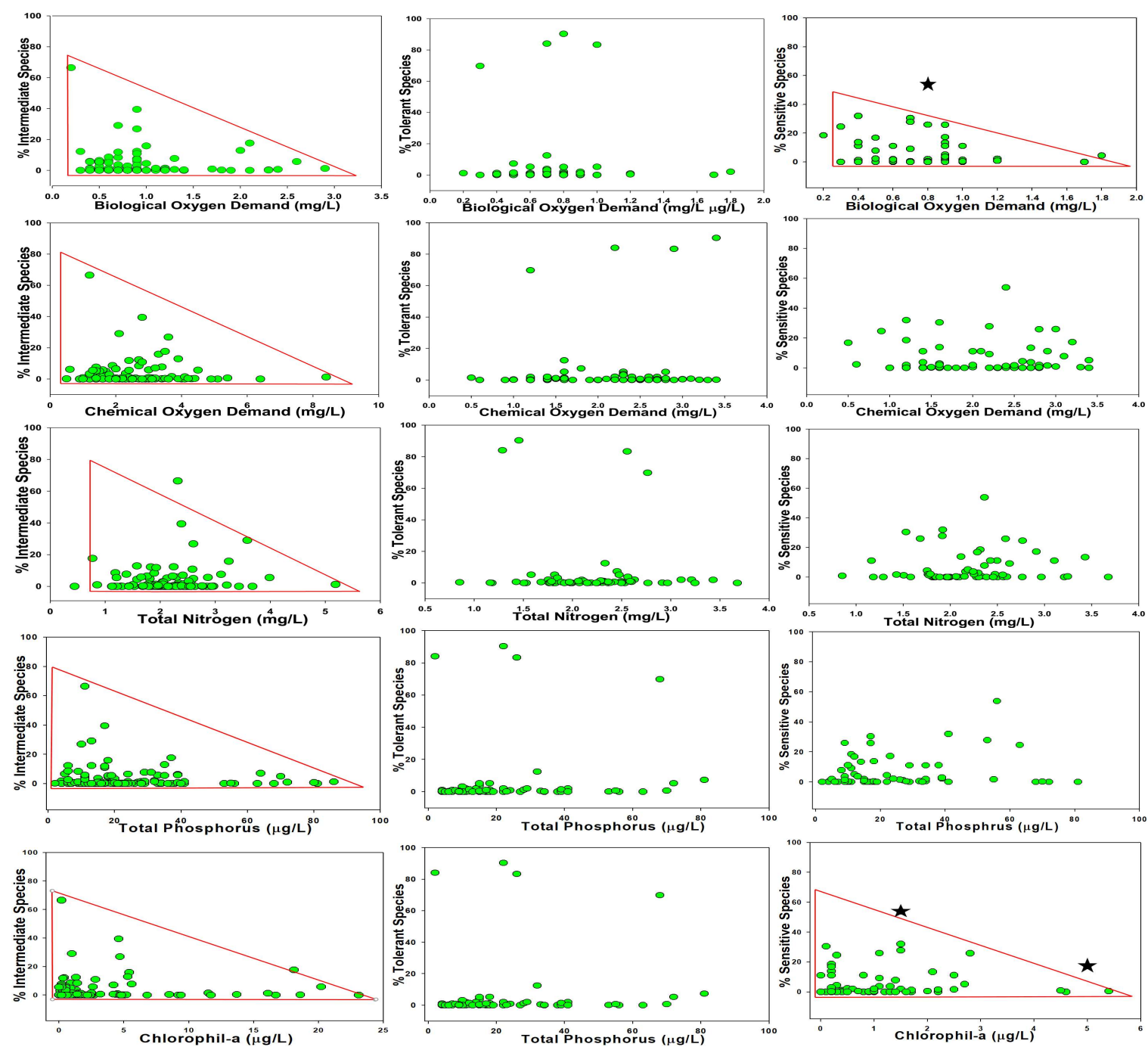

Figure 11. Relationship of tolerance guild to selected water quality parameters in Bouchung Stream. The proportions of intermediate (IS), tolerant (TS), and sensitive (SS) species against BOD, COD, TN, $\mathrm{TP}$, and chlorophyll-a. The red marked boundaries depict an abundance trend of species affected by the relevant water quality parameter. 

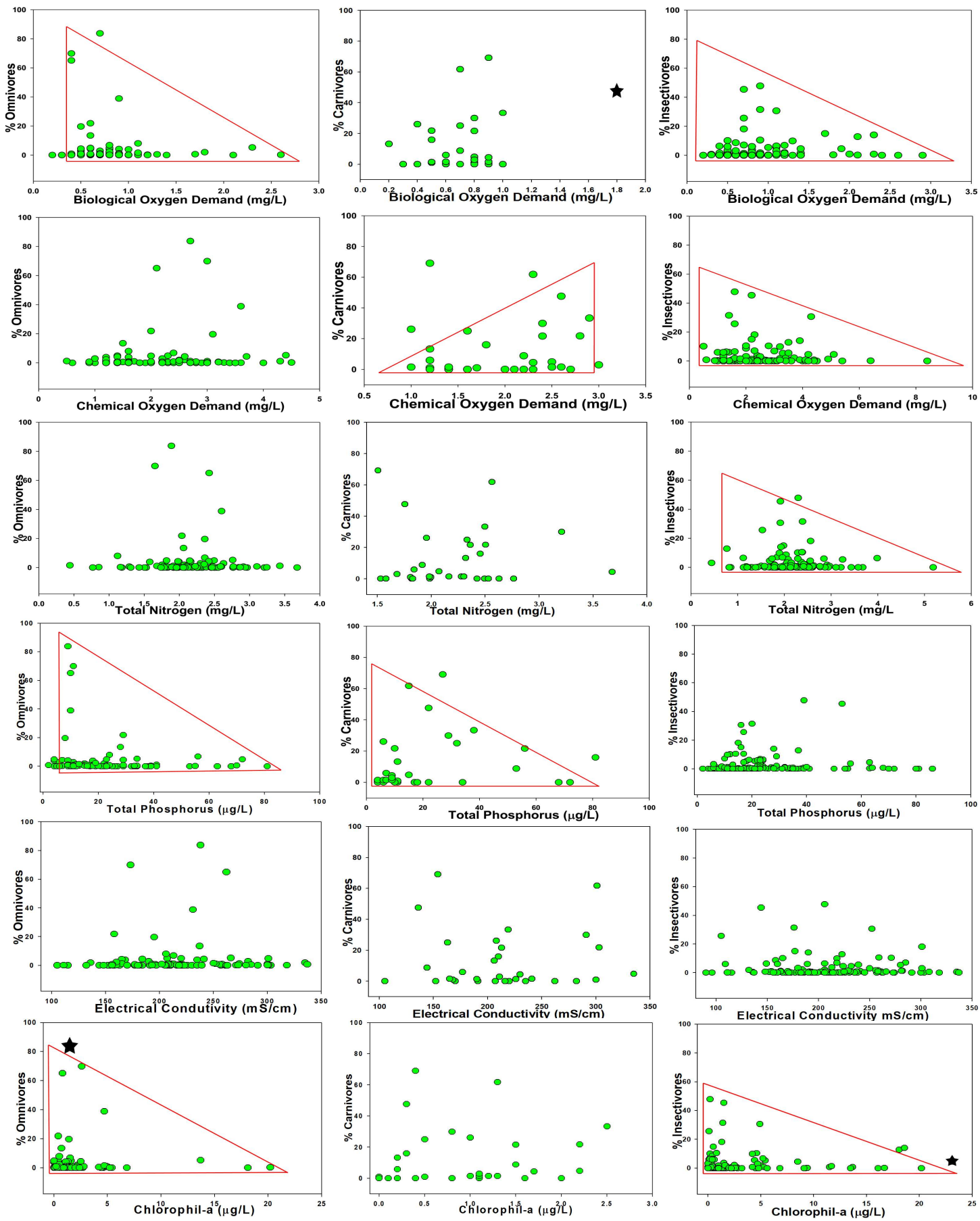

Figure 12. Relationship of trophic guild to selected water quality parameters in Bouchung Stream. The proportion of omnivore $(\mathrm{O})$, carnivore $(\mathrm{C})$, and insectivore $(\mathrm{I})$ species against $\mathrm{BOD}, \mathrm{COD}, \mathrm{TN}, \mathrm{TP}$, EC, and chlorophyll-a. The red marked shapes indicate the trend in species affected by the relevant quality parameter. 

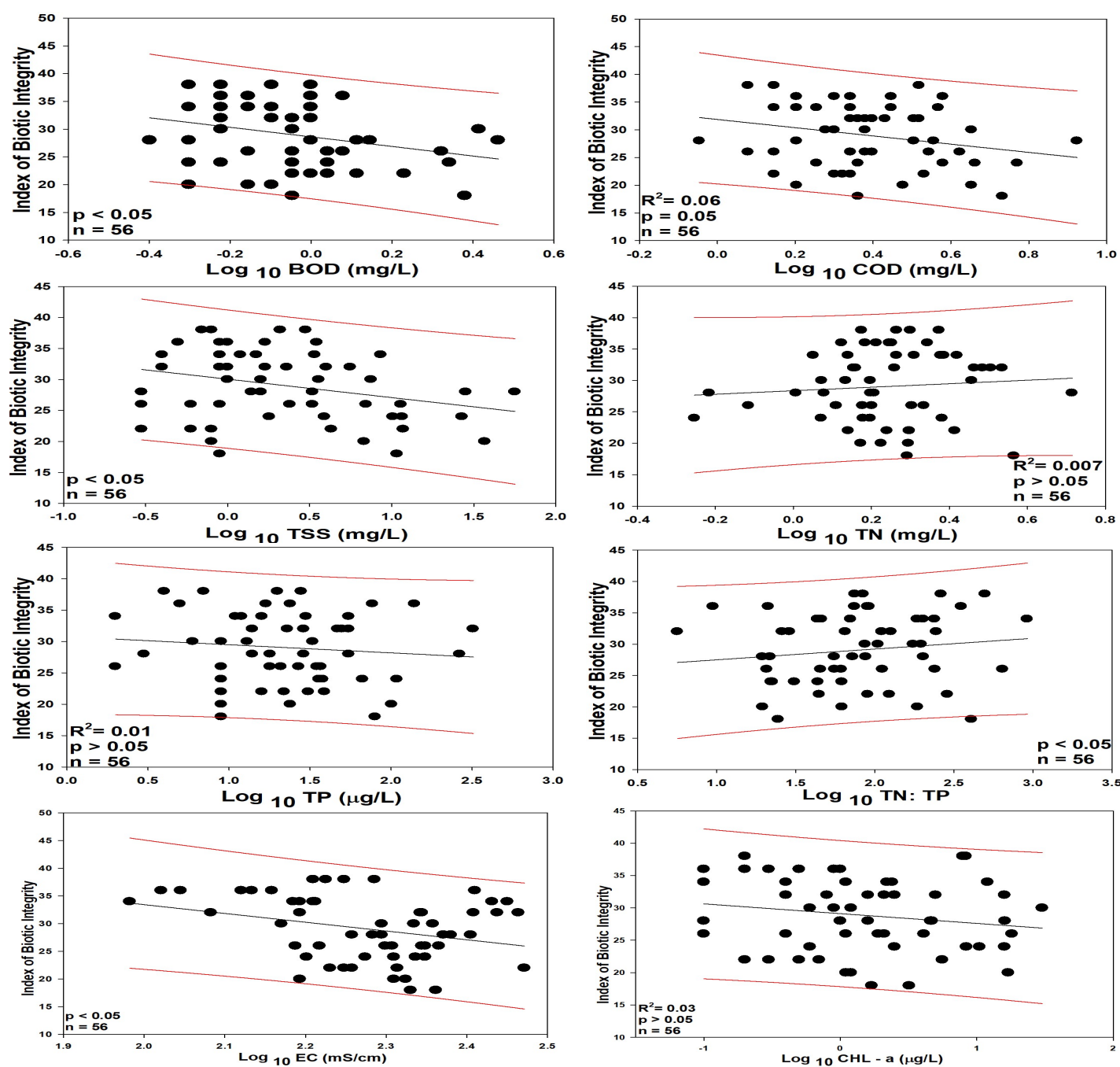

Figure 13. Regression analysis on the index of biotic integrity (IBI) and log-transformed selected water chemistry factors.

\subsection{Key Ecological Factor Identification with PCA}

Principal component analysis (PCA) used for the distribution of biological components and selected water quality factors from the headwaters to downstream region [76]. Results indicated that the stream regions could be divided into distinct headwater, mid-stream, and downstream regions (Figure 14). In the PCA ordination, it accounted for $71.96 \%$ cumulative percent variance in first six principal components (PC). However, axes I and II cumulatively accounted for $37.68 \%$ variance in the data matrix of biological (IS, SS, TS, intermediate, omnivores, and carnivores) and physicochemical (BOD, COD, EC, TSS, TN, TP, TN:TP ratio, and CHL-a etc.) indicators. The first PC explained the most of water chemistry factors but the loading strength was weak $(r=0.30-0.50)$ (Table 5). The second PC showed moderately strong $(r=0.50-0.70)$ loading strength for TN and other allied chemical species.

Table 5. Principal component analysis factor loading values in Bouchung Stream during 2008-2014.

\begin{tabular}{ccccccc}
\hline Factors & PC $\mathbf{1}$ & PC $\mathbf{2}$ & PC $\mathbf{3}$ & PC $\mathbf{4}$ & PC $\mathbf{5}$ & PC $\mathbf{6}$ \\
\hline $\mathrm{pH}$ & 0.07 & -0.11 & 0.39 & -0.16 & 0.25 & 0.12 \\
$\mathrm{DO}$ & -0.29 & 0.18 & 0.19 & -0.14 & -0.06 & 0.01 \\
$\mathrm{BOD}$ & 0.22 & 0.19 & -0.09 & -0.27 & 0.25 & 0.01 \\
$\mathrm{COD}$ & 0.33 & 0.10 & 0.11 & -0.21 & 0.14 & 0.08 \\
\hline
\end{tabular}


Table 5. Cont.

\begin{tabular}{ccccccc}
\hline Factors & PC 1 & PC 2 & PC 3 & PC 4 & PC 5 & PC 6 \\
\hline TSS & 0.29 & 0.12 & 0.10 & 0.02 & -0.01 & 0.16 \\
TN & -0.09 & 0.46 & -0.11 & -0.13 & -0.13 & 0.15 \\
TP & 0.46 & 0.20 & 0.02 & 0.05 & -0.10 & 0.08 \\
TN:TP & -0.31 & 0.03 & 0.03 & -0.13 & 0.03 & 0.13 \\
Temp. & 0.32 & -0.13 & -0.19 & 0.12 & -0.02 & -0.01 \\
EC & -0.10 & 0.12 & 0.21 & -0.40 & 0.08 & -0.13 \\
TDN & -0.13 & 0.45 & -0.13 & -0.09 & -0.12 & 0.12 \\
$\mathrm{NH}_{4}-\mathrm{N}$ & 0.08 & -0.57 & -0.27 & -0.04 & 0.10 & -0.06 \\
$\mathrm{NO}_{3}-\mathrm{N}$ & -0.24 & 0.51 & -0.13 & 0.06 & -0.21 & 0.14 \\
TDP & -0.45 & 0.18 & -0.16 & 0.19 & -0.17 & -0.03 \\
PO 4 -P & 0.53 & 0.14 & -0.08 & 0.23 & -0.16 & -0.03 \\
CHL-a & 0.29 & 0.08 & 0.13 & -0.25 & 0.13 & -0.50 \\
WPI & 0.06 & 0.32 & -0.50 & 0.20 & 0.09 & -0.34 \\
IBI & 0.06 & 0.28 & 0.58 & 0.16 & 0.02 & -0.37 \\
IS & -0.07 & -0.05 & -0.19 & 0.24 & 0.58 & 0.20 \\
TS & 0.12 & -0.04 & 0.11 & -0.15 & -0.50 & 0.43 \\
SS & -0.11 & 0.10 & 0.11 & 0.32 & 0.28 & 0.44 \\
Omnivores & -0.08 & 0.13 & 0.27 & 0.43 & 0.36 & 0.57 \\
Carnivores & -0.06 & 0.00 & -0.02 & 0.14 & 0.03 & -0.58 \\
Insectivores & -0.04 & 0.12 & -0.48 & -0.11 & -0.50 & -0.05 \\
Eigenvalue & 3.26 & 1.84 & 1.40 & 1.30 & 1.07 & 0.87 \\
\% Variance & 24.10 & 13.58 & 10.34 & 9.57 & 7.91 & 6.46 \\
CPV & 24.10 & 37.68 & 48.02 & 57.59 & 65.50 & 71.96 \\
\hline
\end{tabular}

Temp. $=$ Water temperature; WPI = Water pollution index; IBI = Index of biotic integrity; IS = Intermediate species; $\mathrm{TS}=$ Tolerant species; $\mathrm{SS}=$ Sensitive species; $\mathrm{CPV}=$ Cumulative percent variance.

Third compartment explained a moderately strong relationship between WPI and IBI. The fifth and sixth PCs explained the negative relationship between TS and SS, as well as between carnivores and omnivores. The headwater stream populated by sensitive species with TN and DO confirmed the chemical health condition was near to excellent and least impaired by the anthropogenic activities (Figure 14). The mid-stream area showed rapidly changing water quality like TP, TDP, $\mathrm{PO}_{4}-\mathrm{P}$, $\mathrm{NH}_{4}-\mathrm{N}$, and BOD also mostly populated by the intermediate species. The mid-stream region acted as transitional zone. It was mostly impaired due to the agricultural and WWTP effluents. The third compartment was the downstream region that was mainly home to the increasing tolerant species with higher loading values of water quality parameters such as $\mathrm{pH}$, temperature, TSS, and CHL-a along with direct influence of chemical pollution (COD) indicating the role of industrial activities downstream. Overall, the PCA showed the downstream region having greater influence of chemical and nutrient contributing factors, because of anthropogenic activities like WWTP and agricultural runoff that played key roles in the trophic and tolerance guild distribution [7].

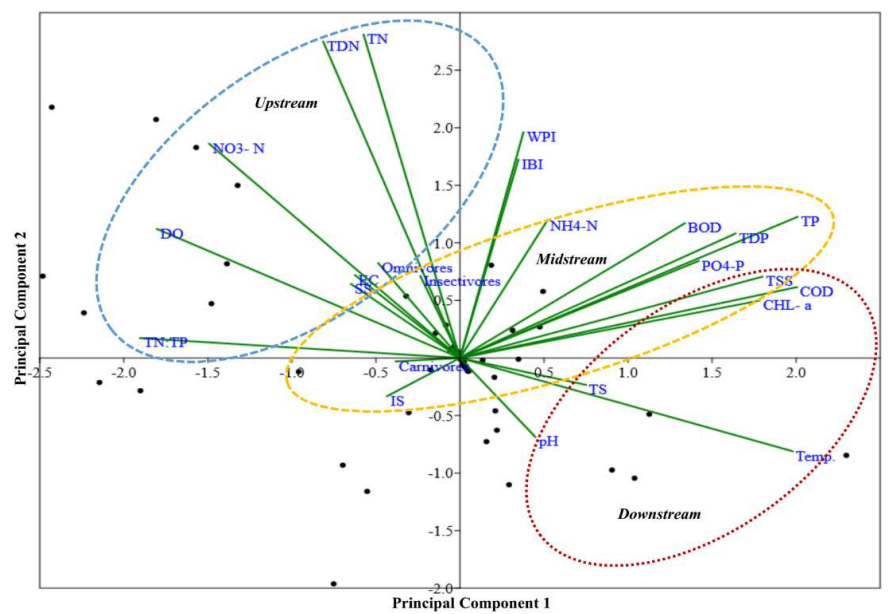

Figure 14. Principal component analysis (PCA) of Bouchung Stream. (The dotted circles indicate upstream, mid-stream, and downstream areas in relation to water chemical parameters and fish guild compositions). 


\section{Conclusions}

In conclusion, we observed that the headwater stream had near to pristine conditions displaying the least influence of human perturbations. However, the anthropogenic effects became clearer downstream, which may be linked to WWTP, industrial unit effluents, as well as agricultural runoff. The results obtained by WPI and IBI approximated each other spatially, and the PCA showed tolerant species increasing in downstream and escalating levels of nutrient contributing factors along with chemical pollution. Increasing nutrient contributing factor levels coupled with higher COD and higher abundance of tolerant species could predict increasing pollutants that may lead to severe ecological degradation. This joint approach of WPI and $\mathrm{IBI}_{\mathrm{KR}}$ as well as the water quality status showed that the monsoon was a key factor which can change the fish assemblages and nutrient inflows. Overall, these analyses successfully clarified the evaluation of chemical and biological health of the stream and could be applied in future studies.

Author Contributions: U.A. conceived the idea, designed the experiments, analyzed the data, prepared the illustrations and the manuscript under the supervision of K.-G.A.

Acknowledgments: Two funds supported this research. One from "Chungnam National University (CNU 2017)" and the other one by "Daejeon Green Environment Center" under the Research Development Program (Year 2017). Therefore, the authors would like to acknowledge these institutions for their assistance.

Conflicts of Interest: The authors declare no conflict of interest.

\section{References}

1. Barbour, M.T.; Gerritsen, J.; Snyder, B.D.; Stribling, J.B. Rapid Bioassessment Protocols for Use in Streams and Wadeable Rivers: Periphyton, Benthic Macroinvertebrates and Fish, 2nd ed.; EPA 841-B-99-002; U.S. Environmental Protection Agency, Office of Water: Washington, DC, USA, 1999; p. 235.

2. Long, J.M.; Walker, D.J. Small scale application and assessment of an Index of Biotic Integrity for a large boreal river. Hydrobiologia 2005, 544, 177-187. [CrossRef]

3. Dahl, J.; Johnson, R.K.; Sandin, L. Detection of organic pollution of streams in southern Sweden using benthic macroinvertebrates. Hydrobiologia 2004, 516, 161-172. [CrossRef]

4. Böhmer, J.; Rawer-Jost, C.; Zenker, A.; Meier, C.; Feld, C.K.; Biss, R.; Hering, D. Assessing streams in Germany with benthic invertebrates: Development of a multimetric invertebrate based assessment system. Limnologica 2004, 34, 416-432. [CrossRef]

5. Noble, R.A.A.; Cowx, I.G.; Starkie, A. Development of fish-based methods for the assessment of ecological status in English and Welsh rivers. Fish. Manag. Ecol. 2007, 14, 495-508. [CrossRef]

6. Choi, J.W.; Kumar, H.K.; Han, J.H.; An, K.G. The development of a regional multimetric fish model based on biological integrity in lotic ecosystems and some factors influencing the stream health. Water Air Soil Pollut. 2011, 217, 3-24. [CrossRef]

7. Kim, J.Y.; An, K.G. Integrated Ecological River Health Assessments, Based on Water Chemistry, Physical Habitat Quality and Biological Integrity. Water 2015, 7, 6378-6403. [CrossRef]

8. Dudgeon, D. Large-scale hydrological changes in tropical Asia: Prospects for riverine biodiversity the construction of large dams will have an impact on the biodiversity of tropical Asian rivers and their associated wetlands. BioScience 2000, 50, 793-806. [CrossRef]

9. Ouyang, Y.; Higman, J.; Thompson, J.; O’Toole, T.; Campbell, D. Characterization and spatial distribution of heavy metals in sediment from Cedar and Ortega rivers sub-basin. J. Contam. Hydrol. 2002, 54, 19-35. [CrossRef]

10. Cooper, M.J.; Uzarski, D.G.; Burton, T.M.; Rediske, R.R. Macroinvertebrate community composition, chemical/physical variables, land use and cover, and vegetation types within a Lake Michigan drowned river mouth wetland. Aquat. Ecosyst. Health Manag. Soc. 2006, 9, 463-479. [CrossRef]

11. Burcher, C.L.; Valett, H.M.; Benfield, E.F. The land-cover cascade: Relationships coupling land and water. Ecology 2007, 88, 229-242. [CrossRef]

12. Stoddard, J.L.; Larsen, D.P.; Hawkins, C.P.; Johnson, R.K.; Norris, R.H. Setting expectations for the ecological condition of streams: The concept of reference condition. Ecol. Appl. 2006, 16, 1267-1276. [CrossRef] 
13. Qadir, A.; Malik, R.N. Assessment of an index of biological integrity (IBI) to quantify the quality of two tributaries of river Chenab, Sialkot, Pakistan. Hydrobiologia 2009, 621, 127-153. [CrossRef]

14. An, K.G.; Park, S.S.; Shin, J.Y. An evaluation of a river health using the index of biological integrity along with relations to chemical and habitat conditions. Environ. Int. 2002, 28, 411-420. [CrossRef]

15. Lee, J.H.; An, K.G. Integrative restoration assessment of an urban stream using multiple modeling approaches with physical chemical, and biological integrity indicators. Ecol. Eng. 2014, 62, 153-167. [CrossRef]

16. Karr, J.R. Assessment of biotic integrity using fish communities. Fisheries 1981, 6, 21-27. [CrossRef]

17. Barbour, M.T.; Gerritsen, J.; Griffity, G.E.; Frydenborg, R.; McCarron, E.; White, J.S.; Bastian, M.L. A framework for biological criteria for Florida streams using benthic macroinvertebrates. J. N. Am. Benthol. Soc. 1996, 15, 185-211. [CrossRef]

18. Yoder, C.O.; Rankin, E.T. The role of biological indicators in a state water quality management process. Environ. Monit. Assess. 1998, 51, 61-88. [CrossRef]

19. Bach, E. A chemical index for surveillance of river water quality. Dtsch. Gewasserkd. Mitt. 1980, 24, $102-106$.

20. Trivedi, R.C.; De-Kruijf, H.A.M.; de-Zwart, D. The development and application of a yardstick for water quality evaluation. Sci. Total Environ. 1993, 134, 1191-1202. [CrossRef]

21. Dodds, W.K.; Jones, J.R.; Welch, E.B. Suggested classification of stream trophic state: Distributions of temperate stream types by chlorophyll, total nitrogen and phosphorus. Water Res. 1998, 32, 1455-1462. [CrossRef]

22. Lee, H.J.; An, K.G. The Development and Application of Multi-metric Water Quality Assessment Model for Reservoir Managements in Korea. Korean J. Limnol. 2009, 42, 242-252.

23. Atique, U.; An, K.G. Water quality assessment based on chemical parameters and the chlorophyll dynamics in relation to nutrient regime in Chungju Reservoir. Pol. J. Environ. Stud. 2018, in press.

24. Leopold, A. A Sand County Almanac, and Sketches Here and There; Oxford University Press, Inc.: New York, NY, USA, 1989.

25. Angermeier, P.L.; Karr, J.R. Biological integrity versus biological diversity as policy directives. Bioscience 1993, 4, 690-697. [CrossRef]

26. Karr, J.R. Ecological integrity and ecological health are not the same. In Engineering within Ecological Constraints; Schulze, P., Ed.; National Academy Press: Washington, DC, USA, 1996; pp. 100-113.

27. Karr, J.R.; Chu, E.W. Restoring Life in Running Waters: Better Biological Monitoring; Island Press: Washington, DC, USA, 1999.

28. Karr, J.R. Biological integrity: A long-neglected aspect of water resource management. Ecol. Appl. 1991, 1, 66-84. [CrossRef] [PubMed]

29. Karr, J.R. Seven foundations of biological monitoring and assessment. Biol. Ambient. 2006, 20, 7-18.

30. Westra, L. Ecological integrity. In Encyclopedia of Science, Technology, and Ethics; Mitcham, C., Ed.; Macmillan Reference: New York, NY, USA, 2005; Volume 2, pp. 574-578.

31. Dale, V.H.; Beyeler, S.C. Challenges in the development and use of ecological indicators. Ecol. Indic. 2001, 1, 3-10. [CrossRef]

32. Niemi, G.J.; McDonald, M.E. Application of ecological indicators. Annu. Rev. Ecol. Evol. Syst. 2004, 35, 89-111. [CrossRef]

33. Wilson, M.J.; Bayley, S.E. Use of single versus multiple biotic communities as indicators of biological integrity in northern prairie wetlands. Ecol. Indic. 2012, 20, 187-195. [CrossRef]

34. Ruaro, R.; Gubiani, E.A. A scientometric assessment of 30 years of the index of biotic integrity in aquatic ecosystems: Applications and main flaws. Ecol. Indic. 2013, 29, 105-110. [CrossRef]

35. Medeiros, H.R.; Bochio, G.M.; Ribeiro, M.C.; Torezan, J.M.; Anjos, L. Combining plant and bird data increases the accuracy of an index of biotic integrity to assess conservation levels of tropical forest fragments. J. Nat. Conserv. 2015, 25, 1-7. [CrossRef]

36. Zampella, R.A.; Bunnell, J.F.; Laidig, K.J.; Procopio, N.A. Using multiple indicators to evaluate the ecological integrity of a coastal plain stream system. Ecol. Indic. 2006, 6, 644-663. [CrossRef]

37. Joy, M.K.; Death, R.G. Application of the index of biotic integrity methodology to New Zealand freshwater fish communities. Environ. Manag. 2004, 34, 415-428. [CrossRef] [PubMed]

38. Kim, S.; An, K.G. Nutrient regime, N: P ratios and suspended solids as key factors influencing fish tolerance, trophic compositions, and stream ecosystem health. J. Ecol. Environ. 2015, 38, 505-515. [CrossRef]

39. Ganasan, V.; Hughes, R.M. Application of an index of biological integrity (IBI) to fish assemblages of the rivers Khan and Kshipra (Madhya Pradesh), India. Freshw. Biol. 1998, 40, 367-383. [CrossRef] 
40. An, K.G.; Lee, J.Y.; Bae, D.Y.; Kim, J.H.; Hwang, S.J.; Won, D.H.; Lee, J.K.; Kim, C.S. Ecological assessments of aquatic environment using multi-metric model in major nationwide stream watersheds. J. Korean Soc. Water Qual. 2006, 22, 796-804.

41. Choi, J.W.; Han, J.H.; Park, C.S.; Ko, D.G.; Kang, H.I.; Kim, J.Y.; Yun, Y.J.; Kwon, H.H.; An, K.G. Nutrients and sestonic chlorophyll dynamics in Asian lotic ecosystems and ecological stream health in relation to land-use patterns and water chemistry. Ecol. Eng. 2015, 79, 15-31. [CrossRef]

42. American Public Health Association (APHA). Standard Methods for the Examination of Water and Wastewater, 21st ed.; American Public Health Association: New York, NY, USA, 2005.

43. Crumpton, W.G.; Isenhart, T.M.; Mitchell, P.D. Nitrate and organic N analyses with second-derivative spectroscopy. Limnol. Oceanogr. 1992, 37, 907-913. [CrossRef]

44. Eaton, A.D.; Franson, M.A.H. Standard Methods for the Examination of Water and Wastewater; American Public Health Association: Washington, DC, USA, 2005.

45. Prepas, E.E.; Rigler, F.A. Improvements in qualifying the phosphorus concentration in lake water. Can. J. Fish. Aquat. Sci. 1982, 39, 822-829. [CrossRef]

46. The Ministry of Environment (MOE). Standard Methods for the Examination of Water Quality Contamination, 7th ed.; Gwacheon Korea, 2000; p. 435. (In Korean)

47. An, K.G.; Yeom, D.H.; Lee, S.K. Rapid Bioassessments of Kap Stream Using the Index of Biological Integrity. Korean J. Environ. Biol. 2001, 19, 261-269.

48. The Ministry of Environment/National Institute of Environmental Research (MOE/NIER). The Survey and Evaluation of Aquatic Ecosystem Health in Korea; The Ministry of Environment/National Institute of Environmental Research (NIER): Incheon, Korea, 2008.

49. United States Environmental Protection Agency (U.S. EPA). Fish Field and Laboratory Methods for Evaluating the Biological Integrity of Surface Waters; EPA 600-R-92-111; Environmental Monitoring Systems Laboratory-Cincinnati Office of Modeling, Monitoring Systems, and Quality Assurance Office of Research Development; U.S. EPA: Cincinnati, OH, USA, 1993; p. 348.

50. Kim, I.S.; Park, J.Y. Freshwater Fish of Korea; Kyohak Publishing: Seoul, Korea, 2002; p. 465.

51. Nelson, J.S. Fishes of the World, 4th ed.; John Wiley \& Sons: New York, NY, USA, 2006; p. 624.

52. Sanders, R.E.; Milter, R.J.; Yondr, C.O.; Rankin, E.T. The use of external deformities, erosion, lesions, and tumors (DELT anormalies) in fish assemblages for characterizing aquatic resources: A case study of seven Ohio streams. In Assessing the Sustainability and Biological Integrity of Water Resources Using Fish Communities; Simon, T.P., Ed.; CRC Press: Boca Raton, FL, USA, 1999; pp. 225-245.

53. An, K.G.; Kim, D.S.; Kong, D.S.; Kim, S.D. Integrative assessments of a temperate stream based on a multimetric determination of biological integrity, physical habitat evaluations, and toxicity tests. Bull. Environ. Contam. Toxicol. 2004, 73, 471-478. [CrossRef] [PubMed]

54. Rankin, E.T.; Yoder, C.O. Adjustments to the index of biotic integrity: A summary of Ohio experiences and some suggested modifications. In Assessing the Sustainability and Biological Integrity of Water Resources Using Fish Communities; Simon, T.P., Ed.; CRC Press: Boca Raton, FL, USA, 1999; p. 672.

55. Sigma Plot, version 10; Systat Software, Inc.: San Jose, CA, USA; Available online: www.systatsoftware.com (accessed on 13 April 2018).

56. Hammer, Ø. The Past of the Future; PAST, Version 3.18 (Software); Natural History Museum, University of Oslo: Oslo, Norway, 2018.

57. Krishnaram, H.; Mohan, M.; Ramchandra; Vishalkashi, Y. Limnological studies on Kolaramma lake Kolar, Karnataka. Environ. Ecol. 2007, 52, 364-367.

58. Vijayakumar, S.K.; Rajesh, K.M.; Mendon, R.; Hariharan, V. Seasonal distribution and behavior of nutrients with reference to tidal rhythm in the Mulki estuary, Southwest coast of India. J. Mar. Biol. Assoc. India 2000, 42, 21-31.

59. Manivasakam, N. Physico-Chemical Examination of Water, Sewage and Industrial Effluents; Pragati Prakashan: New Delhi, India, 2003.

60. Scott, T.M.; Salina, P.; Portier, K.M.; Rose, J.B.; Tamplin, M.L.; Farra, S.R.; Koo, A.; Lukasik, J. Geographical variation in ribotype profiles of Escherichia coli isolates from human, swan, poultry, beef and dairy cattle in Florida. Appl. Environ. Microbiol. 2003, 69, 1089-1092. [CrossRef] [PubMed]

61. Pipes, W.O. Bacteriological Indicators of Pollution; CRC Press: Boca Raton, FL, USA, 1981; p. 242. 
62. Sood, A.; Singh, K.D.; Pandey, P.; Sharma, S. Assessment of bacterial indicators and physicochemical parameters to investigate pollution status of Gangetic river system of Uttarakhand (India). Ecol. Indic. 2008, 8, 709-717. [CrossRef]

63. Han, J.H.; Kim, B.; Kim, C.; An, K.G. Ecosystem health evaluation of agricultural reservoirs using multi-metric lentic ecosystem health assessment (LEHA) model. Paddy Water Environ. 2014, 12 (Suppl. 1), 7-18. [CrossRef]

64. Carlson, R.E. Expanding the trophic state concept to identify non-nutrient limited lakes and reservoirs. In Proceedings of a National Conference on Enhancing the States Lake Management Programs; North American Lake Management Society: Chicago, IL, USA, 1991; pp. 59-71.

65. Lind, O.T.; Terrell, T.T.; Kimmel, B.L. Problems in reservoir trophic-state classification and implications for reservoir management. In Comparative Reservoir Limnology and Water Quality Management; Straskraba, M., Tundisi, J.G., Duncan, A., Eds.; Kluwer Academic Publishers: Dordrecht, The Netherlands, 1993; pp. 57-67.

66. Hill, W.R.; Ryon, M.G.; Schilling, E.M. Light limitation in a stream ecosystem: Responses by primary producers and consumers. Ecology 1995, 76, 1297-1309. [CrossRef]

67. Song, E.S.; Jeon, S.M.; Lee, E.J.; Park, D.J.; Shin, Y.S. Long-term trend analysis of chlorophyll a and water quality in the Yeongsan River. Korean J. Ecol. Environ. 2012, 45, 302-313.

68. Downing, J.A.; McCauley, E. The nitrogen: Phosphorus relationship in lakes. Limnol. Oceanogr. 1992, 37, $936-945$. [CrossRef]

69. Smith, V.H. Low nitrogen to phosphorus ratios favor dominance by blue-green algae in Lake Phytoplankton. Science 1983, 221, 669-671. [CrossRef] [PubMed]

70. An, K.G.; Jones, J.R. Temporal and spatial patterns in ionic salinity and suspended solids in a reservoir influenced by the Asian monsoon. Hydrobiologia 2000, 436, 179-189. [CrossRef]

71. Fujimoto, N.; Sudo, R. Nutrient-limited growth of Microcystis aerugimosa and phormidium tenue and competition under various N:P supply ratios and temperatures. Limnol. Oceonogr. 1997, 42, 250-256. [CrossRef]

72. Seppala, J.; Tamminen, T.; Kaitala, S. Experimental evaluation of nutrient limitation of phytoplankton communities in the Gulf of Riga. J. Mar. Syst. 1999, 23, 107-126. [CrossRef]

73. Han, J.H.; An, K.G. Chemical Water Quality and Fish Community Characteristics in the Mid- to Downstream Reach of Geum River. Korean J. Environ. Biol. 2013, 31, 180-188. [CrossRef]

74. An, K.G.; Kim, J.H. A Diagnosis of Ecological health Using a Physical Habitat Assessment and Multimetric Fish Model in Daejeon Stream. Korean J. Limnol. 2005, 38, 361-371.

75. Bae, E.Y.; An, K.G. Stream Ecosystem Assessments, based on a Biological Multimetric Parameter Model and Water Chemistry Analysis. Korean J. Limnol. 2006, 39, 198-208.

76. McCune, B.; Mefford, M.J. PC-ORD: Multivariate Analysis of Ecological Data; MjM Software Design: Gleneden Beach, OR, USA, 1999.

(C) 2018 by the authors. Licensee MDPI, Basel, Switzerland. This article is an open access article distributed under the terms and conditions of the Creative Commons Attribution (CC BY) license (http://creativecommons.org/licenses/by/4.0/). 